\title{
Structure of the oligotrophic planktonic food web under low grazing of heterotrophic bacteria: Takapoto Atoll, French Polynesia
}

\author{
A. Sakka ${ }^{1, *}$, L. Legendre ${ }^{1, * *}$, M. Gosselin ${ }^{2}$, B. Delesalle ${ }^{3}$ \\ ${ }^{1}$ Département de biologie, Université Laval, Québec, Québec G1K 7P4, Canada \\ ${ }^{2}$ Département d'océanographie, Université du Québec à Rimouski, 310 Allée des Ursulines, Rimouski, \\ Québec G5L 3A1, Canada \\ ${ }^{3}$ Ecole Pratique des Hautes Etudes, Laboratoire de Biologie Marine et Malacologie, URA CNRS 1453, \\ Université de Perpignan, 66860 Perpignan Cedex, France
}

\begin{abstract}
The study investigates the planktonic food web of an oligotrophic atoll lagoon (Takapoto, French Polynesia). The growth $(k)$ and grazing mortality $(g)$ rates of heterotrophic bacteria, cyanobacteria, and $1-3 \mu \mathrm{m}$ and $>3 \mu \mathrm{m}$ (large) algae were assessed, in the presence and absence of the large grazers (>35 $\mu \mathrm{m}$ protozoa), by serial dilution experiments. Taxa-specific feeding relationships were obtained from fluorescently labeled prey uptake experiments. The major consumers of $0.4 \mu \mathrm{m}$ bacteria were aplastidic nanoflagellates ( $7 \mu \mathrm{m}$ Leucocryptos and $10 \mu \mathrm{m}$ Halosphaera), and those of 3-5 $\mu \mathrm{m}$ chlorophyceae (Nannochloropis and Chlamydomonas) were heterotrophic dinoflagellates (32 $\mathrm{mm}$ Achradina and $33 \mu \mathrm{m}$ Prorocentrum). The protozoa exerted a low grazing pressure on heterotrophic bacteria, even when the large grazers were removed (mean values: $g=0.26 \mathrm{~d}^{-1}$ ). In contrast, the grazing rates of $\leq 200 \mu \mathrm{m}$ protozoa on cyanobacteria (mean values: $g=0.43 \mathrm{~d}^{-1}$ ), which were the dominant primary producers, represented $74 \%$ of their growth rates. In absence of the $>35 \mu \mathrm{m}$ grazers, the grazing on cyanobacteria increased, being 4 times higher than on heterotrophic bacteria. These results indicate that, in an oligotrophic planktonic food web where the consumption of bacteria is low, the grazing of protozoa on cyanobacteria is a major carbon pathway. Large algae were grazed at rates equivalent to their growth rates (mean values: $g=0.47 \mathrm{~d}^{-1} ; k=0.50 \mathrm{~d}^{-1}$ ), which implies a steady-state situation with rapid cycling of the algal biomass. In samples without the $>35 \mu \mathrm{m}$ grazers, the grazing mortality and growth rates of large phytoplankton increased significantly, indicating a close coupling between the growth of $>3 \mu \mathrm{m}$ algae and grazing pressure under natural conditions. This coupling is likely mediated by increased nutrient regeneration. The results indicate that the large protozoan consumers controlled the grazing pressure and nutrient regeneration of the small protozoa, which in turn controlled the abundance of phytoplankton and growth of large algae. It follows that the structure of the oligotrophic planktonic food web under low grazing on bacteria is ultimately governed by protozoan microzooplankton.
\end{abstract}

KEY WORDS: Atoll lagoon - Coral reef - Planktonic food web · Protozoan grazing - Dilution method · Fluorescent-labeled prey method

\section{INTRODUCTION}

The planktonic food web has been the focus of renewed attention during the past 2 decades (e.g. Azam 1998). It was shown that the microbial food web

\footnotetext{
- Present address: Département des sciences naturelles, Faculté de Bizerte, Université Tunis II, Bizerte (Zarzouna), 7021, Tunisia

•Corresponding author. E-mail: louis.legendre@bio.ulaval.ca
}

may be a major link between phytoplankton and meso- or macrozooplankton, especially when the algae are dominated by pico- and nanoplankton (Nielsen et al. 1993) and under oligotrophic conditions (Roman et al. 1988). This link is mediated by microzooplankton (Azam et al. 1983, E. B. Sherr et al. 1986). Indeed, the small protozoa $(<20 \mu \mathrm{m})$, which have high growth rates (Riegman et al. 1993, Sherr \& Sherr 1994), can graze on autotrophic picoplankton (Bernard \& Rassoulzadegan 1993, Liu et al. 1995) and nanoplankton (Verity 1991. 
Sherr \& Sherr 1994) at high rates. The grazing of protozoa on phytoplankton was estimated to be as high as $100 \%$ of the algal production in the Arabian Sea (Reckermann \& Veldhuis 1997) and in coastal waters of the western Gulf of St. Lawrence, Canada (Tamigneaux et al. 1997). The small grazers are preyed upon by large microzooplankton (Gifford 1988, Reckermann $\&$ Veldhuis 1997). The latter are themselves likely controlled by metazoan meso- or macrozooplankton (Paffenhöfer 1998), which cannot efficiently capture such small prey as small protozoa (Sanders \& Wickham 1993). It follows that microzooplankton are often trophic intermediates between pico- and nanophytoplankton and large metazoans (E. B. Sherr et al. 1986, Sime-Ngando et al. 1995). In marine ecosystems dominated by the microbial food web, the protozoa exert a strong grazing pressure on autotrophic pico- and nanoplankton and on heterotrophic bacteria. When the grazing by protozoa on heterotrophic bacteria dominates the food web, the system becomes an almost closed microbial loop (Rassoulzadegan 1993). Hence, the dominance of one trophic structure over the other depends on the magnitude of microzooplankton grazing on heterotrophic bacteria relative to small phytoplankton.

The grazing rate of microzooplankton on heterotrophic bacteria is believed to be in the same range as bacterial production in most marine, freshwater and coral reef systems (Rassoulzadegan \& Sheldon 1986, Ducklow 1990, Van Wambeke et al. 1996, Vörös et al. 1996, Ferrier-Pagès \& Gattuso 1998). Since bacteria play a major role in the cycling of materials in planktonic systems (Azam et al. 1983, B. F. Sherr et al. 1986), the grazing mortality rates of bacteria largely determine the fate of bacterial carbon and, therefore, the structure of the planktonic food web. This, in turn, influences the export of biogenic carbon (Legendre \& Le Fèvre 1995). The fate of bacterial carbon depends on its consumption efficiency and the number of steps in the aquatic food web (Azam et al. 1983, Miller et al. 1995). Phagotrophic flagellates, which are generally 5 to $10 \mu \mathrm{m}$ in size, and small aloricate ciliates are the main consumers of bacteria in most planktonic systems (Rassoulzadegan 1993, Simek et al. 1995, Havskum \& Hansen 1997). In addition, dinoflagellates may indirectly graze bacteria by ingestion of bacterivorous protozoa (Lessard \& Swift 1985). The feeding rates of bacterivorous protozoa depend on several factors, which include the abundance, size, growth state, and motility of prey. The clearance and ingestion of flagellates are both functions of food concentration, the clearance rate being inverse hyperbolically related to bacterial concentration (Sherr ef al. 1983). When bacterial abundances fall below a threshold, no detectable ciliate feeding occurs (Banse 1982). Phagotrophic flagellates (Andersson et al. 1986, González 1996) and ciliates (Simek et al. 1994, Christaki et al. 1998) selectively remove the largest bacteria, so that a small size may provide bacteria with a refuge from predation. Laboratory and field experiments have shown that protozoa preferentially remove growing or dividing cells (Sherr et al. 1992, González et al. 1993) and motile bacteria (González et al. 1993). It follows that morphological and physiological characteristics of bacteria may have, through their influence on the consumption rates of bacterivorous protozoa, a significant effect on the structure and functioning of planktonic food webs.

Relatively little is known about the grazing activity of protozoa in coral reef systems, compared to oceanic waters. This trophic compartment is still under-studied in most atoll lagoons. Since the magnitude of grazing on heterotrophic bacteria relative to pico- and nanophytoplankton determines the type of planktonic food web, the present study addresses the structure of the food web in the lagoon of Takapoto Atoll based on the grazing mortality caused by protozoa on different planktonic compartments. Similar to other oligotrophic environments, primary production in the lagoon of Takapoto is dominated by cyanobacteria. Prochlorophytes are present, but their contributions to the chlorophyll a (chl a) biomass and phytoplankton production are negligible, i.e. 4 and $2 \%$, respectively. Bacterial production is low (Torréton \& Dufour 1996), but the numerical abundance of heterotrophic bacteria is higher than generally reported in other oligotrophic and coral reef systems. To explain this apparent paradox, we hypothesized that the heterotrophic bacteria, which are very small in the lagoon $10.035 \mathrm{\mu m}^{3}$, or $0.4 \mu \mathrm{m}$ diam.), are grazed by protozoa at low rates. Hence, the grazing of protozoa on cyanobacteria and/or algae is expected to be high. If so, the major trophic pathway would be the grazing of protozoa on phytoplankton, not on heterotrophic bacteria, thus resulting in a structure of the planktonic food web that differs from the usual microbial loop and microbial food web. The alternative hypothesis is that the grazing of protozoa on bacteria is high, but protozoa cannot efficiently control bacterial abundances because they are themselves controlled by larger microzooplankton grazers. This implies that the grazing of small protozoa should increase after the removal of large microzooplankton.

In order to test the above hypotheses, we estimated and compared the grazing activities of small protozoa on heterotrophic bacteria, cyanobacteria and algae in the presence and absence of the large microzooplankton grazers by using the dilution protocol. In addition, the fluorescently labeled prey method was used to determine taxa-specific feeding characteristics. 


\section{MATERIALS AND METHODS}

Study site. Takapoto Atoll $\left(14^{\circ} 30^{\prime} \mathrm{S}, 145^{\circ} 20^{\prime} \mathrm{W}\right)$ (Fig. 1) is located in the North Tuamotu Archipelago (French Polynesia). The lagoon has an area of $81 \mathrm{~km}^{2}$ and a mean depth of $25 \mathrm{~m}$ (Charpy 1996). Exchanges between the ocean and the lagoon are by reef flat spillways (10 $\mathrm{m}$ wide, $50 \mathrm{~cm}$ deep) in the reef rim. Water residence time in the lagoon is about $4 \mathrm{yr}$ (Sournia \& Ricard 1976), and water temperature is between 28 and $30^{\circ} \mathrm{C}$.

Serial dilution grazing experiments. Experimental procedure: In order to estimate the grazing of microzooplankton on heterotrophic bacteria and phytoplankton, 4 experiments were performed in April 1996 (DiluI-96 and DiluII-96) and 1997 (DiluI-97 and DiluII-97) using a modified version of the dilution protocol of Landry \& Hassett (1982). Water samples were taken at $2 \mathrm{~m}$ depth at $\operatorname{Stn} 9$ (Fig. 1). The station is representative of mean lagoon conditions (Charpy et al. 1997). Some water samples were prescreened through a $35 \mu \mathrm{m}$ mesh and others through a $200 \mu \mathrm{m}$ mesh, in order to determine the grazing pressure of the $\leq 35 \mu \mathrm{m}$ protozoa (absence of $>35 \mu \mathrm{m}$ grazers) and the whole $\leq 200 \mu \mathrm{m}$ microzooplankton assemblage (presence of the $>35 \mu \mathrm{m}$ grazers), respectively. Water samples were diluted, or not, with particle-free lagoon water (prefiltered through a Gelman $0.2 \mu \mathrm{m}$ minicapsule filter) to obtain dilution factors of 100 (no dilution), 80,60 and $40 \%$ of natural water. For each experiment, the 4 dilution mixtures were dispensed in triplicate in 21 polycarbonate acidcleaned flasks, which were incubated in situ at $2 \mathrm{~m}$ for

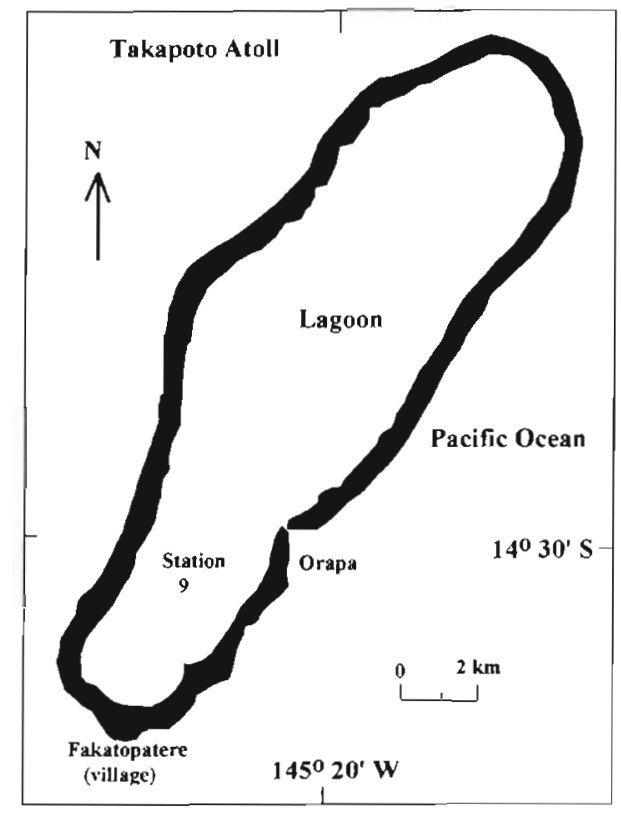

Fig. 1. Takapoto Atoll, French Polynesia: location of the sampling station
$24 \mathrm{~h}$. In 1997, the flasks were amended with nitrate (final concentration of $20 \mu \mathrm{M}$ ) and glucose (final concentration of $5 \mu \mathrm{M}$ ), or with nitrate, glucose, and phosphate (final concentration of $1.5 \mu \mathrm{M}$ ). At the beginning and the end of the experiment, each dilution mixture was sampled for determination of chl $a_{1}$ and abundances of heterotrophic bacteria, phytoplankton, and microzooplankton. Additional samples of natural water were taken for nutrient analysis.

Treatment of water samples: Nutrients were analyzed on liquid-N-frozen samples, according to Parsons et al. (1984), using an Alpkem autoanalyzer. Samples were size-fractionated by sequentially filtering $1000 \mathrm{ml}$ of water on 3,1 and $0.2 \mu \mathrm{m}$ polycarbonate Nuclepore filters, and chl a was determined using a Turner Fluorometer model 112 according to the method described in Parsons et al. (1984).

Samples for the identification and enumeration of large algae ( 2 size classes: 3 to 5 and $>5 \mu \mathrm{m}$ ) and microzooplankton ( 2 size classes: $\leq 35$ and $>35 \mu \mathrm{m}$ ) were preserved in buffered $0.22 \mu \mathrm{m}$ prefiltered formaldehyde (final concentration of $1 \%$ ). Cell abundances were determined under the inverted microscope (Utermöhl 1931, Lund et al. 1958) on $100 \mathrm{ml}$ settled volumes.

Samples for enumeration of heterotrophic bacteria, cyanobacteria, and small algae $(<3 \mu \mathrm{m})$ were preserved in buffered $0.22 \mu \mathrm{m}$ prefiltered formaldehyde (final concentration of $2 \%$ ). Bacteria were counted after DAPI (4'6-diamidino-2-phenylindole) staining (final concentration of $1.8 \mu \mathrm{g} \mathrm{ml}^{-1}$ ) (Hobbie et al. 1977, Porter \& Feig 1980 ) and collection on $0.22 \mu \mathrm{m}$ black polycarbonate Nuclepore filters. Cyanobacteria and small algae were also enumerated on $0.22 \mu \mathrm{m}$ black polycarbonate Nuclepore filters, but without staining, taking advantage of their natural red-orange and red-dull fluorescence, respectively, when excited with green light (Booth 1987). Cell enumeration was done within $5 \mathrm{wk}$ of sampling at $\times 1000$ using a Leitz Dialux 22 epifluorescence microscope.

Algal cell numbers were converted to carbon biomass by applying standard geometric shapes to the cells and using conversion factors of $0.25 \mathrm{pg} \mathrm{C}$ cell $^{-1}$ for

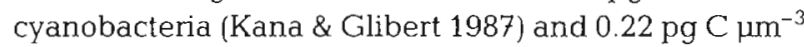
for eucaryotic phytoplankton (Booth 1988). Bacterial cell carbon was estimated to be $10.54 \mathrm{fg} \mathrm{C}$ bacteria $^{-1}$, using the equation: $y=88.6 x^{0.59}$ (Simon \& Azam 1989) where $x$ is the mean cell volume $\left(0.035 \mu \mathrm{m}^{3}\right.$, or $0.4 \mu \mathrm{m}$ in diam.) and $y$ is cell protein (fg), the C:protein ratio being equal to 0.86 . The carbon biomasses of heterotrophic bacteria were estimated by multiplying their cell carbon by the abundances.

Calculation. For each algal size fraction, the chl a concentration and the carbon biomass were used in turn to calculate the apparent growth rate $\left(r_{i} \mathrm{~d}^{-1}\right)$ using the exponential model given by Landry \& Hassett (1982): 


$$
\begin{aligned}
N_{t} & =N_{0} e^{(k-g) t} \\
I & =\ln \left(N_{t} / N_{0}\right) t^{-1}=k-g
\end{aligned}
$$

where $N_{0}$ and $N_{t}$ are chl a concentrations or algal carbon biomasses at the beginning and the end of the experiment, respectively, $k$ and $g\left(d^{-1}\right)$ are the specific growth and grazing mortality rates of phytoplankton, respectively, and $t$ is the time. Eqs. (1) \& (2) were also used to estimate the growth and grazing mortality rates of heterotrophic bacteria, using $N_{0}$ and $N_{1}$ as the initial and final bacterial carbon biomasses during the experiment, respectively. For both phytoplankton and heterotrophic bacteria, $k$ and $g$ were determined from linear regressions on the dilution plots, i.e. $\ln \left(N_{t} / N_{0}\right) t^{-1}=f$ (dilution factor). The negative slope of the line is $g$ and the $y$-intercept is $k$. The significance of the regression line was $t$-tested. All regression statistics were significant $(p<0.05)$, so all data from the serial dilution experiments were used for the calculations.

The numbers of doublings per day of phytoplankton and heterotrophic bacteria were calculated as:

$$
\text { doublings } \mathrm{d}^{-1}=k / \ln 2=1.44 k
$$

The consumption rates of the carbon biomasses of phytonlankton and heterotrophic bacteria were calculated as:

$$
\text { consumption rate of carbon }\left(\mu g \mathrm{C}^{-1} \mathrm{~d}^{-1}\right)=g \times C_{0}
$$

where $C_{0}$ is the carbon biomass of phytoplankton or bacteria in the undiluted control at the beginning of the experiment. The percentage of algal or bacterial production consumed was calculated as $100 \mathrm{~g} / \mathrm{k}$.

The abundances of $\leq 35 \mu \mathrm{m}$ protozoa were used to calculate their gross growth rate as:

$$
z^{\prime}\left(d^{-1}\right)=\ln \left(P_{l} / P_{0}\right) t^{-1}
$$

where $P_{0}$ and $P_{t}$ are the initial and final numbers of $\leq 35 \mu \mathrm{m}$ protozoa, respectively, in the experiments without the $>35 \mu \mathrm{m}$ grazers, and $t$ is the time. The net growth rate of $\leq 35 \mu \mathrm{m}$ protozoa, $z\left(d^{-1}\right)$, was calculated with Eq. (5) using the values from experiments with the $>35 \mu \mathrm{m}$ grazers. The grazing rate on $\leq 35 \mu \mathrm{m}$ protozoa was computed as:

$$
g^{\prime}\left(d^{-1}\right)=z^{\prime}-z
$$

The percentage of $\leq 35 \mu \mathrm{m}$ protozoan production consumed was calculated as $100 \mathrm{~g}^{\prime} / \mathrm{z}^{\prime}$

Statistical analyses: In order to test the effect of $>35 \mu \mathrm{m}$ grazers on $\leq 35 \mu \mathrm{m}$ protozoan grazing, $t$-tests were used to compare the values from experiments with and without the large grazers. Analyses of variance (ANOVAs) were used to compare averages among the 4 experiments (Dilul-96, Dilull-96, Dilul-97, and Dilull-97) and 3 groups of organisms (bacteria, cyanobacteria, and phytoplankton) for each treatment (presence or absence of the large grazers) and each variable. The conditions of normal distribution (test of Shapiro-Wilk) and homogeneity of variance (Fisher or Bartlett-Box test; Zar 1984) were fulfilled in all cases.

FLB and FLA grazing experiments. The specific grazing activities of heterotrophic flagellates, dinoflagellates, and ciliates on bacteria and algae were assessed by short-term (1 h) uptake of fluorescently labeled bacteria (FLB; Sherr et al. 1987) and algae (FLA; Rublee \& Gallegos 1989), respectively. The FLB and FLA short-term experiments were performed on 7 and 19 April 1997, respectively. In order to estimate the total effect of $\leq 35 \mu \mathrm{m}$ protozoan grazing on bacteria or algae, 2 experiments were performed on 8 and 16 April 1997, during which we determined the long-term (24 h) disappearance of FLB and FLA in the incubated samples (Marrasé et al. 1992, Sherr \& Sherr 1993).

Preparation of FLB and FLA stock solutions: Heatkilled FLB were prepared as described by Sherr et al. (1987). Bacterial cultures were isolated from the water column of Lake St. Charles (Québec, Canada) and grown on yeast extract medium for $2 \mathrm{~d}$. Bacterial isolates were harvested by centrifugation at $22000 \times g$ for $15 \mathrm{~min}$. The bacterial pellets were suspended in a $0.05 \mathrm{M}$ phosphate-buffered saline solution, and stained with 5-(4,6-dichlorotriazin-2-yl) aminofluorescein (DTAF) at $60^{\circ} \mathrm{C}$ for $2 \mathrm{~h}$, after which the cells were washed 3 times with the phosphate-buffered saline solution and suspended in a $0.02 \mathrm{M}$ pyrophosphate saline buffered solution. The stock solution $\left(2 \times 10^{8} \mathrm{FLB} \mathrm{m}^{-1}\right)$ was stored frozen in small volumes $(2 \mathrm{ml})$, as recommended by Sherr et al. (1989). 70\% of 1000 enumerated FLB from the stock solution were $\leq 0.5 \mu \mathrm{m}$ diameter, which corresponds to the size of bacteria in the lagoon of Takapoto Atoll (ca $0.4 \mu \mathrm{m}$ ). Hence, the results of FLB experiments are pertinent to heterotrophic bacteria, not cyanobacteria (ca $0.85 \mu \mathrm{m}$ ).

For preparation of the FLA stock solution, we used the chlorophycean Nannochloris sp. When stained with DTAF, this species has the advantage of producing uniformly bright apple-green fluorescent cells, which are easily distinguishable under epifluorescence microscopy (Rublee \& Gallegos 1989). We followed the method of Rublee \& Gallegos (1989) to prepare the FLA from clonal algal cultures. The procedure to label the algae was that of Sherr et al. (1987), described above, except that centrifugation was done at $800 \times g$ and the cells were resuspended, in addition to the pyrophosphate saline buffered solution, with dimethyl sulfoxide. The latter minimizes cell damage due to freezing (Sherr et al. 1991). The FLA stock solution $\left(7 \times 10^{7}\right.$ FLA ml mas stored in small volurnes in the refrigerator. The FLA were 3 to $4 \mu \mathrm{m}$ diameter, 
which resembles the size of natural Chlorophyceae ( 3 to $5 \mu \mathrm{m}$ ) in the lagoon.

Experimental procedure and calculation: Before use, the FLB and FLA stock solutions were resuspended in the pyrophosphate saline buffered solution $(1: 10)$, vortexed, and sonicated to disaggregate clumped cells. Water samples collected at $2 \mathrm{~m}$ depth at Stn 9 (Fig. 1) were prescreened through a $35 \mu \mathrm{m}$ mesh, before being poured into clear acid-washed $2 \mathrm{l}$ polycarbonate flasks. The samples remained untreated for $30 \mathrm{~min}$, to let the planktonic community recover from handling, after which the FLB or FLA were added. All experiments were performed in triplicate.

Short-term uptake experiments. For the short-term uptake experiments, the FLB and FLA were added at final concentrations of $16 \%$ of the natural bacterial population and $30 \%$ of the natural Chlorophyceae assemblage in the lagoon, respectively. The treated flasks were incubated in situ at $2 \mathrm{~m}$. Subsamples were taken at $15 \mathrm{~min}$ intervals for $60 \mathrm{~min}$. At each sampling time, $20 \mathrm{ml}$ (for the FLB treatment) or $100 \mathrm{ml}$ (for the FLA treatment) of sample were removed from each flask and fixed with $0.5 \%$ (final volume) alkaline Lugol solution followed by $3 \%$ (final volume) boratebuffered formaldehyde and a few drops of thiosulfate sodium solution. This fixation treatment preserves the cells and prevents the egestion of the contents of food vacuoles for flagellates (Sherr et al. 1989). Cells were enumerated using a modification of the protocol of Sherr et al. (1987). The preserved subsamples were settled, using the Utermöhl sedimentation technique, for $48 \mathrm{~h}$ and examined under an inverted microscope equipped with an epifluorescent lamp. This method has the advantage of counting the numbers of FLB or FLA per protozoan cell, and simultaneously identifying and counting the protozoa, which have ingested or not the FLB or FLA. Small subsamples were taken at time zero to determine the exact concentration of FLB or FLA added to the samples. Additional subsamples $(20 \mathrm{ml})$ were taken, stained with DAPI (final concentration of $1.8 \mu \mathrm{g} \mathrm{ml}^{-1}$ ), and filtered on $0.22 \mu \mathrm{m}$ Nuclepore black polycarbonate filters for enumeration of total natural bacteria. Other subsamples $(100 \mathrm{ml})$ were taken and fixed with buffered $0.22 \mu \mathrm{m}$ prefiltered formaldehyde (final concentration of $1 \%$ ) for enumeration of natural 3 to $5 \mu \mathrm{m}$ algae.

The short-term uptake rates of FLB or FLA (prey ind.$^{-1} \mathrm{~h}^{-1}$ ) were calculated for flagellates, dinoflagellates, and ciliates, from the linear portion of the curve of average numbers of FLB or FLA per protozoa as a function of time, by simple regression analysis. The FLB or FLA uptake rates were divided by the number of added FLB or FLA to estimate the hourly individual clearance rate (ICR: $\mu \mathrm{l}$ ind. ${ }^{-1} \mathrm{~h}^{-1}$ ). The grazing rates $(g)$ of the 3 groups of protozoa were calculated from their corresponding individual clearance rates and abundances as:

$$
g\left(\mathrm{~d}^{-1}\right)=
$$

ICR $\times$ abundance of the protozoan group $\times 24 \mathrm{~h}$

For each protozoan group, the individual ingestion rates (IIR: cells ind. ${ }^{-1} h^{-1}$ ) were calculated by multiplying the ICR by the abundances of both fluorescent and natural prey, i.e. FLB + natural heterotrophic bacteria or FLA +3 to $5 \mu \mathrm{m}$ natural algae. The ingestion rates were also expressed in terms of carbon ( $\mu \mathrm{g} \mathrm{C}$ ind.$\left.^{-1} \mathrm{~h}^{-1}\right)$ by converting the prey cell numbers into carbon biomass, using the conversion factors and formula given above for the dilution experiments. Finally, the IIRs of each protoznan group were multiplied by the corresponding total abundance in natural water and by $24 \mathrm{~h}$ to obtain daily rates (cells $\mathrm{l}^{-1} \mathrm{~d}^{-1}$ or $\mu \mathrm{g} \mathrm{Cl}^{-1} \mathrm{~d}^{-1}$ ) of bacteria or 3 to $5 \mu \mathrm{m}$ algae consumed by the whole assemblage of flagellates, dinoflagellates, or ciliates.

Long-term disappearance experiments. The flasks were inoculated with FLB and FLA at a final concentration of $64 \%$ of the natural bacterial numbers and $80 \%$ of the natural 3 to $5 \mu \mathrm{m}$ algae, respectively. The treated flasks were incubated in situ at $2 \mathrm{~m}$. Subsamples were taken every $4 \mathrm{~h}$ for $24 \mathrm{~h}$, and preserved in the same way as for the short-term uptake experiments. The preserved subsamples were filtered on $0.22 \mu \mathrm{m}$ Nuclepore black polycarbonate filters, and the FLB and FLA were counted under a Leitz Dialux 22 epifluorescence microscope, following the method of Sherr et al. (1987). Subsamples were also taken to count the total numbers of natural bacteria and 3 to $5 \mu \mathrm{m}$ algae.

The grazing rates $\left(g, h^{-1}\right)$ were calculated from the rates of disappearance of fluorescent prey (FLB or FLA) as:

$$
g=\ln \left(F_{0} / F_{t}\right) t^{-1}
$$

where $F_{0}$ and $F_{t}$ are initial (at $0 \mathrm{~h}$ ) and final (at $24 \mathrm{~h}$ ) concentrations of FLB or FLA, respectively, and $t$ is the time. The total cell numbers of $<35 \mu \mathrm{m}$ protozoa were converted into total volumes by applying standard geometric shapes to the protozoan cells, and grazing rates were divided by the total volumes of $\leq 35 \mu \mathrm{m}$ protozoa to obtain volume-specific clearance rates (CR: $\mu \mu^{-3} \mathrm{~m}^{-1} \mathrm{~h}^{-1}$ ). The volume-specific ingestion rate for the $\leq 35 \mu \mathrm{m}$ protozoa (IR: cells ingested $\mu \mathrm{m}^{-3} \mathrm{~h}^{-1}$ ) was calculated as in the short-term uptake experiments ( $\mathrm{R}=\mathrm{CR} \times$ cell concentration), the cell concentration being the sum of FLB and natural bacteria or FLA and 3 to $5 \mu \mathrm{m}$ algae. The ingestion rate was expressed in terms of carbon ( $\mu \mathrm{g} C \mu \mathrm{m}^{-3} \mathrm{~h}^{-1}$ ), in the same way as in the short-term uptake experiments. Finally, the daily rate of ingestion of bacteria or 3 to $5 \mu \mathrm{m}$ algae by the whole $\leq 35 \mu \mathrm{m}$ protozoan assem- 


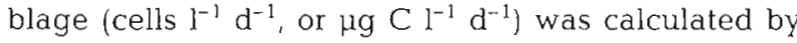
multiplying IR by the total volume of $<35 \mu \mathrm{m}$ protozoa and $24 \mathrm{~h}$.

\section{RESULTS}

\section{Characteristics of the plankton assemblage}

During our study, there was no significant difference between the 2 years for any of the planktonic variables. Hence, all values given below are averages over all experiments. In the lagoon, heterotrophic bacteria were very abundant $\left(1.6 \times 10^{9}\right.$ cells $\left.\mathrm{l}^{-1}\right)$, with a mean carbon biomass of $16.7 \mu \mathrm{g} \mathrm{C} \mathrm{l}^{-1}$. The average algal carbon biomass was $29.5 \mu \mathrm{g} \mathrm{Cl}^{-1}$, and the mean chl a concentration was $0.24 \mu \mathrm{g} \mathrm{l}^{-1}$. The $<1 \mu \mathrm{m}$ size fraction contributed $>50 \%$ to the total chl $a$. The phytoplankton assemblage was numerically dominated by small algae, i.e. cyanobacteria (mean size: $0.85 \mu \mathrm{m}$; $1.8 \times 10^{8}$ cells $\mathrm{l}^{-1}$ ) and $<3 \mu \mathrm{m}$ algae (mean size: $2.5 \mu \mathrm{m} ; 2.9 \times 10^{6}$ cells $\mathrm{l}^{-1}$ ). The assemblage of large (>3 $\mu \mathrm{m}$ ) algae in the lagoon was dominated by 3 to $5 \mu \mathrm{m}$ Chlorophyceae $\left(0.5 \times 10^{6}\right.$ cells $\left.^{-1}\right)$, which represented $68 \%$ of the total number of $>3 \mu \mathrm{m}$ algae (in atoll lagoons: Chlorophyceae are generally not abundant, e.g. Uvea Atoll, New Caledonia; Le Borgne et al. 1997). Dinoflagellates $\left(42 \times 10^{3}\right.$ cells $\left.\mathrm{l}^{-1}\right)$ and coccolithophores $\left(17 \times 10^{3}\right.$ cells $\left.\mathrm{l}^{-1}\right)$ represented 19 and $8 \%$ of $>3 \mu \mathrm{m}$ algal abundances, respectively. For all experiments, the assemblage of large algae was dominated by the following genera: Nannochloropsis ( $3 \mu \mathrm{m}$ ) and Chlamydomonas $(5 \mu \mathrm{m})$ (Chlorophyceae), Gymnodinium $(10 \mu \mathrm{m})$ (dinoflagellates), and Acanthoica $(15 \mu \mathrm{m})$, Corisphaera $(12 \mu \mathrm{m})$ and Syracosphaera (14 $\mu \mathrm{m})$ (coccolithophores).

The $\leq 35 \mu \mathrm{m}$ microzooplankton were mostly dominated by nanoflagellates, which added up to $44 \times 10^{3}$ cells $1^{-1}$. This protozoan group was represented by 3 aplastidic taxa, i.e. Halosphaera $(10 \mu \mathrm{m})$, Leucocryptos $(7 \mu \mathrm{m})$, and Telonema (14 $\mu \mathrm{m})$. In most marine ecosystems, the nanoflagellate assemblage is numerically dominated by $<5 \mu \mathrm{m}$ organisms (Sherr \& Sherr 1991). Because these organisms are fragile and more susceptible to lysis when stored, they were probably underestimated in the present study. The $\leq 35 \mu \mathrm{m}$ heterotrophic dinoflagellates were also present $\left(7.3 \times 10^{3}\right.$ cells $\left.1^{-1}\right)$, being dominated by Achradina

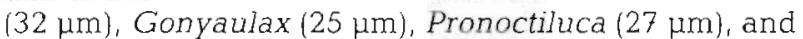
Prorocentrum $(33 \mu \mathrm{m})$. The $\leq 35 \mu \mathrm{m}$ protozoan assemblage also included small oligotrichous naked ciliates $\left(2.0 \times 10^{3}\right.$ cells $\left.\mathrm{l}^{-1}\right)$, mostly represented by Lobeilia (34 $\mu \mathrm{m})$ and Strombidium (12 to $30 \mu \mathrm{m})$. The $>35 \mu \mathrm{m}$ microzooplankton mostly consisted of protozoa, with metazoa (copepod nauplii) being seldom observed.
The 35 to $200 \mu \mathrm{m}$ protozoan assemblage included large dinoflagellates (Amphidiniopsis, $46 \mu \mathrm{m}$; Ornithocercus, $60 \mu \mathrm{m}$; Pomatodinium, $55 \mu \mathrm{m}$ ), tintinnids, which were mostly represented by Favella brebis $(70 \mu \mathrm{m})$, and large oligotrichous ciliates (40 to $55 \mu \mathrm{m}$ ).

\section{Serial dilution experiments}

The initial conditions for each dilution grazing experiment are given in Table 1 . The results of the 4 dilution experiments were used since the slopes of all regressions were significantly different from zero.

Growth and grazing mortality of heterotrophic bacteria

In both the presence and absence of large grazers (>35 $\mu \mathrm{m}$ ), the grazing rates on bacteria were homogeneous among experiments and not significantly different between the 2 treatments (Fig. 2a). For the 3 experiments and 2 treatments, the average grazing on bacteria was $0.25 \mathrm{~d}^{-1}$. The mean consumption rate of bacterial carbon biomass was $4.3 \mu \mathrm{g} \mathrm{Cl}^{-1} \mathrm{~d}^{-1}$. On average, protozoan bacterivory corresponded to $28 \%$ of

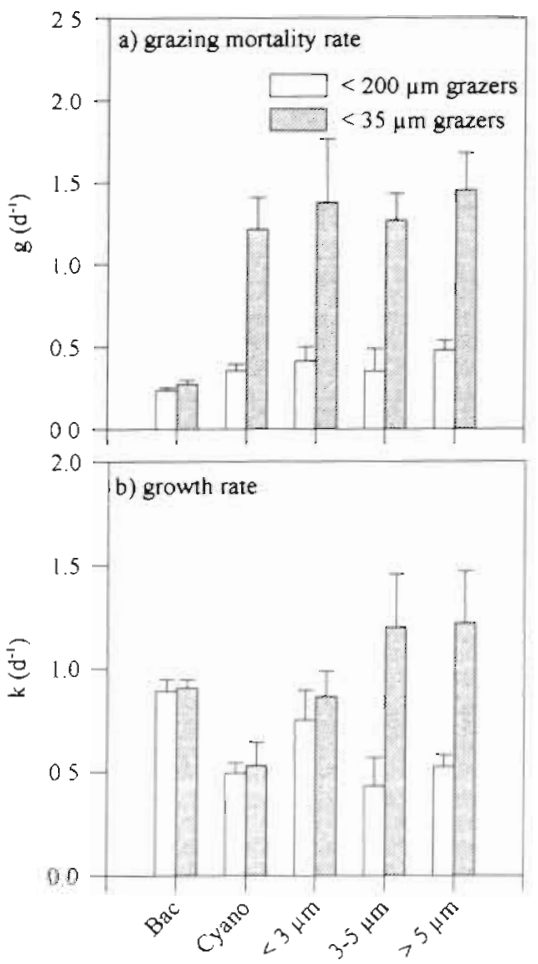

Fig. 2. Grazing mortality $(g)$ and growth $(k)$ rates of heterotrophic bacteria, cyanobacteria, and $<3,3$ to 5 and $>5 \mu \mathrm{m}$ algae from dilution experiments with $<200$ and $<35 \mu \mathrm{m}$ grazers (averages of the 4 experiments $+\mathrm{SD}$ ) 
bacterial growth. The growth rates of bacteria were the same in the presence or absence of the $>35 \mu \mathrm{m}$ consumers (Fig. 2b). They were not different between the 1996 and 1997 experiments, despite the fact that the DiluI-97 flasks were enriched with nitrate + glucose. The mean growth rate was $0.9 \mathrm{~d}^{-1}$, which gives a value of 1.3 doublings $\mathrm{d}^{-1}$.

\section{Growth and grazing mortality of phytoplankton}

Fig. 2 also gives the results of dilution experiments for algal carbon. In each treatment and for each algal group, the estimated variables were homogeneous among experiments. The grazing rates on cyanobacteria were 3 times higher without the $>35 \mu \mathrm{m}$ grazers than with them (1.2 and $0.4 \mathrm{~d}^{-1}$, respectively; Fig. 2a). On average, $5 \mu \mathrm{g}$ of cyanobacterial carbon were consumed per litre daily by the $\leq 200 \mu \mathrm{m}$ grazers, the rate being 3 times higher ( $15 \mu \mathrm{C} \mathrm{Cl}^{-1} \mathrm{~d}^{-1}$ ) without the large grazers. The growth rates of cyanobacteria were the same for the 2 treatments (Fig. 2b), the mean value being $0.5 \mathrm{~d}^{-1}$, which gives a value of 0.7 doublings $\mathrm{d}^{-1}$. Total microzooplankton grazing was $74 \%$ of cyanobacterial growth, the percentage being $>190 \%$ when the $\leq 35 \mu \mathrm{m}$ protozoa only were present.

As observed for cyanobacteria, the grazing rates on algae by the $\leq 35 \mu \mathrm{m}$ protozoa alone were significantly higher than those estimated for the whole microzooplankton assemblage (Fig, 2a). This was true for the 3 algal size classes $(<3,3$ to 5 , and $>5 \mu \mathrm{m})$. The mean grazing rates for $\leq 200 \mu \mathrm{m}$ microzooplankton were 0.4 , 0.4 , and $0.5 \mathrm{~d}^{-1}$, respectively, the grazers consuming 2 , 1 , and $5 \mu \mathrm{g} \mathrm{C} \mathrm{l}^{-1} \mathrm{~d}^{-1}$ of the 3 algal size classes, respectively. In the absence of the $>35 \mu \mathrm{m}$ grazers, the mean grazing rates on the 3 algal size classes were 1.4, 1.3, and $1.5 \mathrm{~d}^{-1}$, respectively, the mean carbon consumption rates by the $<35 \mu \mathrm{m}$ grazers being 7,4 , and $14 \mu \mathrm{g} \mathrm{C} \mathrm{l}^{-1} \mathrm{~d}^{-1}$, respectively. The $<3 \mu \mathrm{m}$ algal growth rates, like those of cyanobacteria above, were not significantly different between treatments (Fig. 2b), their
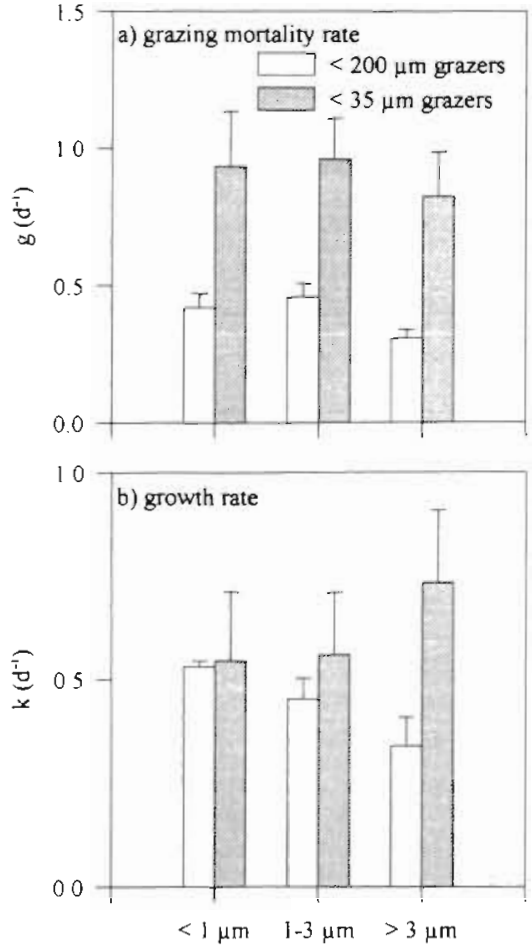

Fig. 3. Grazing mortality $(g)$ and growth $(k)$ rates of $<1,1$ to 3 and $>3 \mu \mathrm{m}$ chl a from dilution experiments with $<200$ and $<35 \mu \mathrm{m}$ grazers (averages of the 4 experiments $+\mathrm{SD}$ )

mean value being $0.8 \mathrm{~d}^{-1}$, or 1.2 doublings $\mathrm{d}^{-1}$. The 3 to 5 and $>5 \mu \mathrm{m}$ algae had similar growth rates. Their mean values with the large grazers present $10.5 \mathrm{~d}^{-1}$, or 0.7 doublings $\mathrm{d}^{-1}$ ) were 2.5 times lower than without them (1.2 $\mathrm{d}^{-1}$, or 1.7 doublings $\mathrm{d}^{-1}$ ) (Fig. 2b). The grazing mortality of algae by total microzooplankton represented 56,80 , and $100 \%$ of algal growth in the 3 size classes, respectively, whereas, in the absence of the large grazers, the $\leq 35 \mu \mathrm{m}$ protozoan grazing was 150 , 108 , and $115 \%$ of algal growth for the respective size classes.

Table 1. Initial conditions in undiluted controls at the beginning of each dilution grazing experiment. nd: not determined. $\mathrm{NO}_{3}$ concentrations are not given because of a technical problem during the analysis

\begin{tabular}{|c|c|c|c|c|c|}
\hline & & DiluI-96 & DiluII-96 & DiluI-97 & DiluII-97 \\
\hline \multicolumn{2}{|l|}{ Date } & 23 Apr 1996 & 30 Apr 1996 & 7 Apr 1997 & 16 Apr 1997 \\
\hline Initial nutrient concentration $(\mu \mathrm{M})$ & $\begin{array}{l}\mathrm{PO}_{4} \\
\mathrm{Si}(\mathrm{OH})_{4}\end{array}$ & $\begin{array}{l}0.17 \\
\text { nd }\end{array}$ & $\begin{array}{l}0.21 \\
\text { nd }\end{array}$ & $\begin{array}{l}0.31 \\
0.16\end{array}$ & $\begin{array}{l}0.07 \\
0.21\end{array}$ \\
\hline \multicolumn{2}{|c|}{ Initial total chl a concentration ( $\mu \mathrm{g} \mathrm{chl} \mathrm{a} \mathrm{l^{-1 } )}$} & 0.23 & 0.24 & 0.25 & 0.24 \\
\hline \multicolumn{2}{|c|}{ Initial total algal carbon biomass ( $\mu \mathrm{g} \mathrm{Cl}^{-1}$ ) } & 29.0 & 31.5 & 31.0 & 26.5 \\
\hline \multicolumn{2}{|c|}{ Initial bacterial carbon biomass $\left(\mu \mathrm{g} \mathrm{C} \mathrm{l^{-1 }}\right)$} & 16.3 & 16.5 & 17.2 & nd \\
\hline \multicolumn{2}{|c|}{ Initial $\leq 35 \mu \mathrm{m}$ protozoan abundance $\left(10^{3}\right.$ cells $\left.\mathrm{l}^{-1}\right)$} & 53.2 & 58.7 & 52.1 & 49.2 \\
\hline
\end{tabular}


The results of dilution grazing experiments are given in Fig. 3 for chl $a$ biomass. The grazing of microzooplankton on phytoplankton was significantly enhanced when the $>35 \mu \mathrm{m}$ grazers were removed (Fig. 3a), this being true for the 3 size fractions. In each treatment and for each size fraction, the grazing rates were homogeneous among experiments. The mean grazing rates of the whole microzooplankton assemblage on the $>3,1$ to 3 and $<1 \mu \mathrm{m}$ chl a were $0.3,0.5$, and $0.4 \mathrm{~d}^{-1}$, respectively. For the $\leq 35 \mu \mathrm{m}$ grazers alone, the grazing rates were $>2$ times those for total microzooplankton, giving mean values of 0.8 , 1.0 , and $0.9 \mathrm{~d}^{-1}$, respectively. Concerning growth rates, only those of $>3 \mu \mathrm{m}$ chl a were enhanced by the removal of large grazers (Fig. $3 b$ ), the mean value being $0.3 \mathrm{~d}^{-1}$ with the large grazers and 2.5 times as high $\left(0.7 \mathrm{~d}^{-1}\right)$ without them. For the $>3 \mu \mathrm{m} \mathrm{chl} a$, the grazing rates represent ca $100 \%$ of the growth rates with or without the $>35 \mu \mathrm{m}$ grazers. For the $<1$ and 1 to $3 \mu \mathrm{m}$ chl a size fractions, the growth rates were not higher when the large grazers were removed, the values being similar for the 2 fractions (mean of $0.5 \mathrm{~d}^{-1}$ ). The total microzooplankton grazing rates represent 100 and $80 \%$ of the growth rates of the 1 to 3 and $<1 \mu \mathrm{m} c h l$ a size fractions, respectively. In the absence of the $>35 \mu \mathrm{m}$ grazers, the $\leq 35 \mu \mathrm{m}$ protozoan grazing was $>170 \%$ of growth in the 2 chl a size fractions.

\section{Growth and grazing mortality of $\leq 35 \mu \mathrm{m}$ protozoa}

Table 2 gives the growth rates of $\leq 35 \mu \mathrm{m}$ protozoa estimated in the presence of the $>35 \mu \mathrm{m}$ grazers (net growth rates), and in their absence (gross growth rates). The difference between the 2 growth rates provides the $>35 \mu \mathrm{m}$ microzooplankton grazing rates on $\leq 35 \mu \mathrm{m}$ protozoa. The 3 estimated variables were homogeneous among experiments. The $\leq 35 \mu \mathrm{m}$ protozoa had a mean gross growth rate $\left(0.44 \mathrm{~d}^{-1}\right) 3$ times higher than their mean net growth rate $\left(0.14 \mathrm{~d}^{-1}\right)$. They were removed by the $>35 \mu \mathrm{m}$ grazers at a rate of $0.3 \mathrm{~d}^{-1}$, which represents $67 \%$ of the small protozoan gross growth.

\section{FLB and FLA short-term uptake experiments}

In the short-term uptake experiments ( $1 \mathrm{~h})$, the incubated samples were prescreened on a $35 \mu \mathrm{m}$ mesh. The experiments thus provide estimates of specific rates for the various protozoan groups $\leq 35 \mu \mathrm{m}$ in size. The results of FLB and FLA short-term uptake experiments are given in Table 3.
Microscopic counts show that phagotrophic flagellates made up a major portion of the bacterivorous protozoa ( $81 \%$ of the protozoa that ingested FLB). Within the flagellate group, the organisms that consumed the FLB belonged to genera Leucocryptos and Halosphaera, which are 7 and $10 \mu \mathrm{m}$ in size, respectively. The heterotrophic dinoflagellates and ciliates were minor components of the bacterivorous protozoa ( 11 and $8 \%$ of the protozoa that ingested FLB, respectively). The former were dominated by the pigmented species Gymnodinium prolatum $(<10 \mu \mathrm{m})$, and the latter were represented by the small oligotrichous ciliate genus Strombidium (12 to $30 \mu \mathrm{m}$ ). The grazing rates were low, with values of 0.06 , 0.0004 , and $0.0007 \mathrm{~d}^{-1}$ for the heterotrophic flagellates, dinoflagellates, and ciliates, respectively. Phagotrophic flagellates had the highest cell-specific clearance and ingestion rates, with values of $0.06 \mu$ ind.$^{-1} \mathrm{~h}^{-1}$ and 108 cells ind.$^{-1} \mathrm{~h}^{-1}$, respectively. For the total nanoflagellate assemblage, the ingestion rate was $114 \times 10^{6}$ bacte-

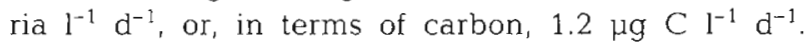
Dinoflagellates and ciliates consumed only 0.7 and $1.4 \times 10^{6}$ bacteria $^{-1} \mathrm{~d}^{-1}$, respectively, their respective ingestion rates being 0.01 and $0.02 \mu \mathrm{g} \mathrm{Cl}^{-1} \mathrm{~d}^{-1}$.

In the FLA short-term uptake experiment, the heterotrophic flagellates, dinoflagellates, and ciliates made up similar proportions of the phytophagous protozoa, i.e. 35,30 , and $35 \%$ of the protozoa that ingested FLA, respectively. Genus Telonema $(14 \mu \mathrm{m})$ was the major flagellate taxon ingesting FLA. The major phytophagous dinoflagellates belonged to Achradina $(32 \mu \mathrm{m})$ and Prorocentrum $(33 \mu \mathrm{m})$. The ciliates that ingested FLA belonged to Lobeilia $(34 \mu \mathrm{m})$ and Strombidium $(31 \mu \mathrm{m})$. Despite the fact that the proportions of the 3 protozoan groups among the phytophagous protozod were similar, dinoflagellates had the highest specific rates of grazing $\left(1.2 \mathrm{~d}^{-1}\right)$, clearance (10.8 $\mathrm{kl} \mathrm{ind}^{-1}$ $\mathrm{h}^{-1}$ ), and ingestion (12.6 algae ind..$^{-1} \mathrm{~h}^{-1}$ ). The ingestion rate of the dinoflagellate assemblage was $1.4 \times 10^{6}$ algae $\mathrm{l}^{-1} \mathrm{~d}^{1}$, giving a daily ingested carbon biomass of $4.3 \mu \mathrm{g} \mathrm{C}{ }^{-1}$. The phagotrophic flagellates had the lowest specific clearance $\left(0.6 \mu \mathrm{l}\right.$ ind $\left.^{-1} \mathrm{~h}^{-1}\right)$ and ingestion $\left(0.8\right.$ algae ind. ${ }^{-1} \mathrm{~h}^{-1}$ ) rates. Their assemblage ingestion rate was $0.8 \times 10^{6}$ algae $\mathrm{l}^{-1} \mathrm{~d}^{-1}$, or $2.5 \mu \mathrm{g} \mathrm{Cl}^{-1} \mathrm{~d}^{-1}$. The ciliates had specific clearance $\left(2.1 \mu l\right.$ ind $\left.^{-1} h^{-1}\right)$ and 
ingestion ( 2.4 algae ind.$^{-1} \mathrm{~h}^{-1}$ ) rates higher than those of flagellates, but their assemblage ingestion rate $\left(0.1 \times 10^{6}\right.$ algae $\mathrm{l}^{-1} \mathrm{~d}^{-1}$, or $\left.0.4 \mu \mathrm{g} \mathrm{C} \mathrm{I}^{-1} \mathrm{~d}^{-1}\right)$ was the lowest because these protozoa were the less abundant group in the protozooplankton.

\section{FLB and FLA long-term disappearance experiments}

Results of the FLB and FLA long-term disappearance experiments (24 h) are given in Table 4 . During these experiments, we calculated the FLB and FLA disappearance rates, which are the grazing rates of the whole $\leq 35 \mu \mathrm{m}$ protozoa assemblage (the incubated samples were prescreened on a $35 \mu \mathrm{m}$ mesh). The results of the FLB and FLA long-term disappearance and dilution experiments without the $>35 \mu \mathrm{m}$ grazers, which both lasted $24 \mathrm{~h}$, can be compared because the 2 types of experiments provide similar information on the $\leq 35 \mu \mathrm{m}$ protozoan grazing activity. In contrast, the results of the short-term uptake and the long-term disappearance experiments cannot be compared because of the different incubation times, i.e. $1 \mathrm{~h}$ for the former and $24 \mathrm{~h}$ for the latter.

During the 2 FLB long-term experiments, the grazing rates were similar, with a mean value of $0.2 \mathrm{~d}^{-1}$. These rates are in the same range as those obtained in the dilution experiments (Fig. 2a). The clearance and ingestion rates had mean values of $0.85 \mathrm{nl} \mathrm{mm}^{-3} \mathrm{~h}^{-1}$ and 2.5 bacteria $\mu \mathrm{m}^{-3} \mathrm{~h}^{-1}$, respectively. The $\leq 35 \mu \mathrm{m}$ protozoan assemblage ingested daily $589 \times 10^{6}$ bacteria $\mathrm{l}^{-1}$ or $6.3 \mu \mathrm{g} \mathrm{Cl}^{-1}$. This carbon ingestion rate is in the same range as the bacterial carbon consumption rates estimated during the serial dilution experiments.

During the 2 FLA long-term experiments, the grazing rates were similar, with a mean value of $1.4 \mathrm{~d}^{-1}$. The grazing rates estimated in the FLA long-term experiments were not different from the grazing coefficients on the 3 to $5 \mu \mathrm{m}$ algae estimated in the dilution experiments, in absence of the $>35 \mu \mathrm{m}$ grazers
(Fig. 2a). The $\leq 35 \mu \mathrm{m}$ protozoan assemblage ingestion rate of carbon $\left(5.6 \mu \mathrm{g} \mathrm{C}^{-1} \mathrm{~d}^{-1}\right)$ was also in the same range as those estimated for the 3 to $5 \mu \mathrm{m}$ algae without the 35 to $200 \mu \mathrm{m}$ grazers.

\section{DISCUSSION}

\section{Estimation of microzooplankton grazing rates}

During the last few decades, several methods have been developed to assess the role of microzooplankton grazing in plankton trophodynamics. Quantifying the grazing rates is, however, still problematic. In the present study, 2 different methods were used to estimate the grazing effects of microzooplankton in the lagoon of Takapoto Atoll, i.e. the dilution technique, which involves the whole community, and the fluorescently labeled prey method, which is based on addition of a tracer.

The dilution method of Landry \& Hassett (1982) has been widely used in plankton research since it provides, in a single experiment, field estimates of growth and grazing mortality for all autotrophic organisms. Even though the technique is not advocated for heterotrophic bacteria (Landry 1993), our results for bacteria (Fig. 2) are similar to those obtained from the FLB long-term experiments (Table 4), which are more appropriate for these organisms. So, the dilution technique also provides, in the present study, a useful index of bacterial grazing mortality. The central assumption of the dilution method is that the grazing rate is proportional to the dilution effect on grazer concentration (dilution factor). As a corollary, the individual clearance rates of microzooplankton must be constant, i.e. independent of the dilution effect on prey concentration. The dilution of samples can, however, reduce prey concentration below a threshold where the grazers' clearance rates are increased. At the other end of the dilution spectrum, prey concentration in undiluted or minorly diluted samples may be

Table 3. FLB and FLA short-term uptake experiments. Grazing rates ( $g$ ), individual clearance rates (ICR), individual ingestion rates (IIR), and assemblage ingestion rates (AIR) for the $\leq 35 \mu \mathrm{m}$ phagotrophic flagellates, dinoflagellates, and ciliates. Values are averages of triplicates $\pm \mathrm{SD}$

\begin{tabular}{|c|c|c|c|c|c|c|}
\hline & $\underset{\left(\mathrm{d}^{-1}\right)}{g}$ & $\begin{array}{c}\text { ICR } \\
\left(\mu l \text { ind } .^{-1} h^{-1}\right)\end{array}$ & (cells ind ${ }^{-1} \mathrm{~h}^{-1}$ ) & $\begin{array}{l}\mathrm{R} \\
\left(\text { pg } \mathrm{C} \text { ind } \mathrm{f}^{-1} \mathrm{~h}^{-1}\right)\end{array}$ & $\begin{array}{r}\mathrm{A} \\
\left(10^{6} \text { cells } 1^{-1} \mathrm{~d}^{-}\right.\end{array}$ & $\left(\mu \mathrm{g} \mathrm{Cl} \mathrm{l}^{-1} \mathrm{~d}^{-1}\right)$ \\
\hline \multicolumn{7}{|c|}{ FLB short-term uptake experiment (7 Apr 1997) } \\
\hline Flagellates & $0.0600 \pm 0.0100$ & $0.057 \pm 0.020$ & $107.6 \pm 44.5$ & $1.13 \pm 0.40$ & $113.6 \pm 47.4$ & $1.20 \pm 0.500$ \\
\hline Dinoflagellates & $0.0004 \pm 0.0001$ & $0.003 \pm 0.001$ & $6.7 \pm 1.2$ & $0.07 \pm 0.01$ & $0.7 \pm 0.05$ & $0.01 \pm 0.002$ \\
\hline Ciliates & $0.0007 \pm 0.0002$ & $0.015 \pm 0.004$ & $27.7 \pm 8.3$ & $0.29 \pm 0.08$ & $1.4 \pm 0.05$ & $0.02 \pm 0.004$ \\
\hline \multicolumn{7}{|c|}{ FLA short-term uptake experiment (19 Apr 1997) } \\
\hline Flagellates & $0.68 \pm 0.03$ & $0.65 \pm 0.03$ & $0.8 \pm 0.06$ & $2.42 \pm 0.8$ & $0.8 \pm 0.07$ & $2.55 \pm 0.93$ \\
\hline Dinoflagellates & $1.20 \pm 0.12$ & $10.82 \pm 0.93$ & $12.6 \pm 1.22$ & $39.23 \pm 3.65$ & $1.4 \pm 0.50$ & $4.28 \pm 0.74$ \\
\hline Ciliates & $0.11 \pm 0.04$ & $2.09 \pm 0.71$ & $2.4 \pm 0.80$ & $7.54 \pm 2.60$ & $0.1 \pm 0.01$ & $0.39 \pm 0.14$ \\
\hline
\end{tabular}


Table 4. FLB and FLA long-term disappearance experiments. Grazing rates ( $g$ ), volume-specific clearance rates (CR), volume-specific ingestion rates (IR), and assemblage ingestion rates (AIR) for the whole $\leq 35 \mu m$ protozoan assemblage. Values are averages of triplicates $\pm S D$

\begin{tabular}{|c|c|c|c|c|c|c|}
\hline & $\begin{array}{c}g \\
\left(\mathrm{~d}^{-1}\right)\end{array}$ & $\begin{array}{c}C R \\
\left(n l \mu m^{-3} h^{-1}\right)\end{array}$ & $\left(10^{-2}\right.$ cells $\mu \mathrm{m}^{-3} \mathrm{~h}$ & $\begin{array}{l}\text { IR } \\
\left.h^{-1}\right)\left(f g C \mu m^{-3} h^{-1}\right)\end{array}$ & $\left(10^{6} \text { cells }\right)^{-1}$ & $\begin{array}{l}\text { AIR } \\
\left.\mathrm{d}^{-1}\right)\left(\mu \mathrm{C} \mathrm{Cl}^{-1} \mathrm{~d}^{-1}\right)\end{array}$ \\
\hline \multicolumn{7}{|c|}{ FLB long-term disappearance experiments } \\
\hline Expt 1 (8 Apr 1997) & $0.22 \pm 0.04$ & $1.00 \pm 0.05$ & $280 \pm 11$ & $8.7 \pm 0.3$ & $707.0 \pm 65.7$ & $7.5 \pm 1.3$ \\
\hline Expt 2 (16 Apr 1997) & $0.18 \pm 0.02$ & $0.70 \pm 0.03$ & $195 \pm 5$ & $6.2 \pm 0.2$ & $470.0 \pm 50.5$ & $5.0 \pm 1.8$ \\
\hline \multicolumn{7}{|c|}{ FLA long-term disappearance experiments } \\
\hline Expt 1 (8 Apr 1997) & $1.38 \pm 0.02$ & $1.10 \pm 0.20$ & $0.40 \pm 0.03$ & $7.5 \pm 1.5$ & $2.0 \pm 0.6$ & $6.2 \pm 1.5$ \\
\hline Expt 2 (16 Apr 1997) & $1.50 \pm 0.03$ & $0.90 \pm 0.10$ & $0.25 \pm 0.05$ & $4.2 \pm 1.6$ & $1.6 \pm 0.4$ & $5.0 \pm 1.0$ \\
\hline
\end{tabular}

above the level that saturates grazers' ingestion, so that the grazers' clearance rates may decrease to keep ingestion constant. In both cases, the relationship between the feeding rate and prey concentration (i.e. the functional feeding response) will not be linear (Landry 1994, Landry et al. 1995), which may be reflected in the dilution plots. Since our dilution plots were significantly linear, we conclude that aur estimated grazing coefficients from the dilution approach are not biased. Another potential problem arises from the fact that serial dilution experiments require relatively long incubations (24 h) to observe a significant change in prey concentration. During the incubations, nutrients may become depleted, which would modify the growth rates. In such a case the relationship between the apparent growth rate and the dilution factor may have an exaggerated negative slope, because nutrient limitation would be a source of prey decrease additional to protozoan grazing, so that the grazing rate would be overestimated. In our dilution experiments, the estimates of growth coefficients for heterotrophic bacteria, cyanobacteria, several algal size classes, and several chl a size fractions without nutrient enrichment (DiluI-96 and DiluII-96) were similar to those obtained with nutrient amended samples (Dilul-97 and DiluII-97). This indicates that, during our $24 \mathrm{~h}$ incubations, the different organisms did not experience nutrient limitation by $\mathrm{N}$ or $\mathrm{P}$. There might have been, however, limitation by other nutrients than $\mathrm{N}$ or $\mathrm{P}$ (e.g. Fe) during the $24 \mathrm{~h}$ incubations.

The FLB and FLA methods of Sherr et al. (1987) and Rublee \& Gallegos (1989), respectively, require shortterm $(1 \mathrm{~h})$ incubations, the duration of which is generally less than the vacuole turnover time. These techniques involve the small addition of a particulate tracer, which causes minor disruption only of the natural assemblage. The FLB and FLA short-term uptake experiments have the advantage of providing visual evidence of phagotrophic activity, and allowing researchers to determine the feeding characteristics of the various microzooplankton groups. In contrast, the FLB and FLA long-term (24 h) disappearance experi- ments assess the grazing activity of the whole microzooplankton community. The 2 types of experiments are not free of problems. Microzooplankton grazing of heat-killed cells may be lower than that of live cells, because of differences in prey size, chemistry, and motility (Sherr et al. 1991, González et al. 1993). Another potential problem is that the grazing pressure on fluorescently labeled prey may be underestimated if preservatives cause egestion of vacuole contents (Sieracki et al. 1987). To avoid this problem, we used the fixation treatment recommended by Sherr et al. (1989). A third potential problem may come from the fact that we added, in our FLB/FLA long-term disappearance experiments, a concentration of prey higher than a tracer concentration (64 and $80 \%$ of the natural concentrations of bacteria and 3 to $5 \mu \mathrm{m}$ algae, respectively), which might cause a change of the functional feeding response of grazers. We think that this problem did not occur in our study because, in the dilution experiments, we got a significant linear grazing response of protozoa over the range of prey dilutions. So, the central assumption of the dilution technique, i.e. the individual clearance rates of grazers must be constant over the range of dilutions, was respected in our experiments. The clearance rates from the dilution experiments with $\leq 35 \mu \mathrm{m}$ grazers (average of the 4 experiments for bacteria: $0.21 \mu l$ ind $^{-1} \mathrm{~h}^{-1}$; for 3 to $5 \mu \mathrm{m}$ algae: $1 \mu \mathrm{l}$ ind $\mathrm{d}^{-1} \mathrm{~d}^{-1}$ ) and from the FLB/FLA long-term experiments (average of the 2 experiments for the FLB and FLA: 0.16 and $1.16 \mu l$ ind.$^{-1} \mathrm{~h}^{-1}$, respectively) were not different. This means that the grazers did not change their clearance rates (as they did in the dilution experiments), which leads us to conclude that the feeding response of protozoa did not change when the FLB/FLA were added at high concentrations during the long-term disappearance experiments.

Despite the fact that the dilution and FLB/FLA protocols may cause artifacts and have limits, these approaches were used simultaneously in the present study to provide detailed information on the grazing activity of protozoa. 


\section{Microzooplankton grazing on heterotrophic bacteria and phytoplankton}

Recent studies have investigated the abundance and production of heterotrophic bacteria and phytoplankton in the lagoon of Takapoto Atoll (Torréton \& Dufour 1996, Charpy \& Blanchot 1998), but none have addressed their grazing mortality and, therefore, their overall role in the carbon flux. The present study simultaneously used 2 experimental approaches to assess the grazing activity of microzooplankton, which makes it the most detailed and complete to date in a coral reef system.

In the lagoons of Takapoto and the nearby Tikehau Atolls, bacterial abundances are higher $(1.6$ and $1.9 \times 10^{9}$ cells $1^{-1}$, present study and González et al. 1998 , respectively) than those generally reported in coral reef systems, e.g. in the lagoons of One Tree Island (Great Barrier Reef, Australia), Majuro Atoll (Marshall Islands) and Miyako Island (Japan), and in Kaneohe Bay (Hawaii), where bacterial concentrations are $0.5,0.9,0.6$, and $0.8 \times 10^{9}$ cells $\mathrm{l}^{-1}$, respectively (Landry et al. 1984, Linley \& Koop 1986, Yoshinaga et al. 1991, Ferrier-Pagès \& Gattuso 1998). Because of the high abundance of bacteria in Takapoto, we hypothesized that their grazing rates by microzooplankton are low (see 'Introduction').

The results of the dilution experiments indicate that the growth rate of bacteria $\left(0.9 \mathrm{~d}^{-1}\right)$ largely exceeded their grazing rate $\left(0.26 \mathrm{~d}^{-1}\right)$, which is not consistent with the fact that bacterial biomass is temporally stable in the lagoon (Torréton \& Dufour 1996). One possible explanation could be that bacterial mortality in the lagoon was higher than in the incubated flasks, because of viral lysis (Fuhrman \& Suttle 1993, Fuhrman \& Noble 1995). This is unlikely, however, because this cause of mortality should not be different in the flasks and in the lagoon. The alternative explanation is higher bacterial growth in the incubation flasks than in the lagoon, as discussed in the remainder of this paragraph. Bacterial production ( $3 \mathrm{mg} \mathrm{C} \mathrm{m}^{-3} \mathrm{~d}^{-1}$ ) was estimated by Sakka et al. (unpubl. data) from [methyl${ }^{3} \mathrm{H}$ ]thymidine incubations. Using this production, the net growth rate of bacteria $\mu=$ production/biomass $\approx$ $3 \mathrm{mg} \mathrm{C} \mathrm{m} \mathrm{m}^{-3} \mathrm{~d}^{-1} / 17 \mathrm{mg} \mathrm{C} \mathrm{m} \mathrm{m}^{-3}=0.2 \mathrm{~d}^{-1}$. This value is 3 times lower than the net growth rate of bacteria calculated from our dilution experiments $\mu=(k-g) \approx$ $0.9-0.3=0.6 \mathrm{~d}^{-1}$. This indicates that bacterial growth in the incubation flasks was probably enhanced, resulting in overestimated growth rates of bacteria. The growth rates of bacteria were not different in 1996 and 1997, despite the enrichment of the DiluI-1997 flasks with nitrate + glucose. This suggests that these resources may have been artificially enhanced by the lysis of fragile cells during the filtration of the water used for sample dilution, which would have caused a stimulation of bacterial growth in the incubated flasks relative to field conditions. In addition, it was shown that ultraviolet- $B$ radiation has negative effects on the growth of heterotrophic bacteria (Herndl et al. 1993, Jeffrey et al. 1996). Hence, another possible cause of bacterial growth enhancement, during our dilution experiments, may have been the reduction of UV-B radiation by the polycarbonate incubation flasks. It follows that the growth rates of bacteria in the lagoon may have been of the same order as their grazing mortality. This would be consistent with reports that, in most marine, freshwater and coral reef systems, protozoa have the potential to graze bacteria at a rate that is equivalent to their growth (Rassoulzadegan \& Sheldon 1986, Coffin \& Sharp 1987, Ducklow 1990, Van Wambeke et al. 1996, Ferrier-Pagès \& Gattuso 1998).

Using the dilution experiment data, we calculated that the $\leq 35 \mu \mathrm{m}$ protozoan assemblage consumed, on average, $4.3 \mu \mathrm{g}$ bacterial $\mathrm{C}^{-1} \mathrm{~d}^{-1}$ or $408 \times 10^{6}$ bacteria $\mathrm{l}^{-1} \mathrm{~d}^{-1}$. This consumption rate may be overestimated because, in the calculation of the consumption rate of carbon (Eq. 4), we considered that all bacteria are grazed by protozoa. This may be incorrect because only $12 \%$ of the bacteria are growing in Takapoto Lagoon (Torréton \& Dufour 1996; frequency of dividing-divided cells), and protozoa are known to select growing and dividing cells (Sherr et al. 1992, González et al. 1993, del Giorgio et al. 1996). For $12 \%$ of growing bacteria, the protozoan consumption rate is $0.65 \mu \mathrm{g}$ $\mathrm{C}^{-1} \mathrm{~d}^{-1}$, or $158 \times 10^{6}$ bacteria $\mathrm{l}^{-1} \mathrm{~d}^{-1}$. This consumption rate is lower than values in other oligotrophic environments such as the Mediterranean Sea $\left(624 \times 10^{6}\right.$ bacteria $\mathrm{I}^{-1} \mathrm{~d}^{-1}$, Hagström et al. 1988), the Red Sea $\left(696 \times 10^{6}\right.$ bacteria $\mathrm{l}^{-1} \mathrm{~d}^{-1}$, Weisse 1989) and the Sargasso Sea $\left(600 \times 10^{6}\right.$ bacteria $\mathrm{l}^{-1} \mathrm{~d}^{-1}$, Davis \& Sieburth 1984). Moreover, the grazing mortality rate of bacteria remained unchanged when the $\leq 35 \mu \mathrm{m}$ consumers were free of predation (Fig. 2a). This implies that the small bacteria of Takapoto are weakly preyed upon by the small grazers. In the lagoon of Takapoto Atoll, bacteria are very small $\left(0.035 \mu \mathrm{m}^{3}\right.$, or $0.40 \mu \mathrm{m}$ diameter; Torréton \& Dufour 1996). This characteristic can explain the low grazing of bacteria by protozoa, which are known to select large cells (González et al. 1990, González 1996). González et al. (1998) similarly found low grazing pressure on heterotrophic bacteria in the lagoon of Tikehau Atoll, where bacteria are small $\left(0.05 \mu \mathrm{m}^{3}\right.$, or $0.46 \mu \mathrm{m}$ diameter $)$.

As previously reported for other marine systems (Sherr et al. 1983, Havskum \& Hansen 1997), aplastidic nanoflagellates are the main bacterivorous protozod in the lagoon of Takapoto Atoll. The individual clearance and ingestion rates of flagellates in Table 3 are in the range of values reported in most marine ecosystems 
(Fenchel 1982a-d, Capriulo 1990). In our study, bacterivory was found to be the primary mode of feeding of Leucocryptos. This finding is in contrast to other investigations, in which this nanoprotozoa mainly grazed on nanophytoplankton (Vors 1992). As mentioned in the 'Results', the $<5 \mu$ m protozoan flagellates may be underestimated in our study because of the preservation method. If so, their contribution to bacterivory would be underestimated, which may explain the very low grazing rates of flagellates on bacteria obtained in the FLB short-term experiments (Table 3). In these experiments, the mixotrophic Gymnodinium prolatum made up $11 \%$ of the numbers of protozoa that ingested FLB. The bacterivory of this dinoflagellate is likely to be indirect, i.e. via the consumption of bacterivorous protozoa, because dinoflagellates ingest cells generally larger than bacteria (Sherr et al. 1991, Sherr \& Sherr 1994). The bacterivorous ciliates in Takapoto belong to the genus Strombidium, whose clearance rates on FLB $\left(0.015 \mu \mathrm{lind} \mathrm{.}^{-1} \mathrm{~h}^{-1}\right)$ are lower than the values reported for 2 species of this oligotrichous genus $\left(0.1\right.$ to 0.5 and 1.1 to $3.1 \mu \mathrm{lind} \mathrm{f}^{-1} \mathrm{~h}^{-1}$, Jonsson 1986). This may indicate that Strombidium had a larger optimum prey size than bacteria, which is consistent with the fact that these organisms ingested not only FLB but also FLA, their clearance rate on FLA being higher than on FLB. This is also consistent with previous reports that the feeding of ciliates is related to prey size (Sherr et al. 1987, González et al. 1990).

In contrast to that of heterotrophic bacteria, the abundance of phytoplankton was largely controlled by microzooplankton grazing. Our results show that the rates of growth and removal by microzooplankton were nearly equal for the 2 size classes of large algae ( 3 to 5 and $>5 \mu \mathrm{m}$; Fig, $2 \mathrm{a}$ ) and $>3 \mu \mathrm{m}$ chl a (Fig. 3a). This implies a steady-state situation with rapid cycling of the biomass of $>3 \mu \mathrm{m}$ algae. The growth rates of small phytoplankton (cyanobacteria and $<3 \mu \mathrm{m}$ algae) generally exceeded their grazing mortality rates by microzooplankton (Figs. 2a,b \& 3a,b), but microzooplankton grazing represented a high percentage of small phytoplankton growth. The grazing rates of microzooplankton on cyanobacteria and $<1 \mu \mathrm{m}$ chl a (mostly cyanobacteria; Charpy \& Blanchot 1998) were 74 and $80 \%$ of their respective growth rates. These percentages are much higher than those found in other aquatic systems such as Kaneohe Bay (20\%, Landry et al. 1984), Miyako Island (30 to $50 \%$, Ferrier-Pagès \& Gattuso 1998) and the Northwest Atlantic (37 to 52\%, Campbell \& Carpenter 1986). Our estimates of microzooplankton grazing rates on cyanobacteria and $<1 \mu \mathrm{m}$ chl a (mean value: $0.4 \mathrm{~d}^{-1}$, Figs. 2a \& 3a) are similar to those reported in other coral reef systems, e.g. in Kaneohe Bay the grazing mortality of cyanobacteria is
0.1 to $0.4 \mathrm{~d}^{-1}$ (Landry et al. 1984, Liu et al. 1995). The cyanobacterial growth rates estimated in the present study (mean values: $0.5 \mathrm{~d}^{-1}$, or 0.8 doublings $\mathrm{d}^{-1}$, Fig. 2b) are, however, lower than those generally reported for oligotrophic tropical waters $\left(1.2\right.$ to $2.9 \mathrm{~d}^{-1}$, Bienfang et al. 1984) and coral reef environments (1 to $1.5 \mathrm{~d}^{-1}$, Landry et al. $1984 ; 1.5$ to 3 doublings $\mathrm{d}^{-1}$, Ferrier-Pagès \& Gattuso 1998). As discussed above, there was no sign of nutrient limitation during our $24 \mathrm{~h}$ dilution incubations, so that the growth rates of cyanobacteria are likely realistic. Hence, it appears that a large part of the cyanobacterial production was grazed by microzooplankton, the values being even higher when the large microzooplankton were removed, i.e. the $\leq 35 \mu \mathrm{m}$ protozoan grazing rates on cyanobacteria then represented $>170 \%$ of the cyanobacterial growth rates. This is significant for the fate of primary production in Takapoto Lagoon, which is dominated by cyanobacteria (Charpy \& Blanchot 1998).

\section{Interactions between grazers and prey}

Trophic interactions among large consumers, firstorder grazers, and prey have been described for various marine planktonic food webs (e.g. Verity \& Smetacek 1996, Reckermann \& Veldhuis 1997). Our data show that the grazing pressure on $>3 \mu \mathrm{m}$ algae increased significantly in the absence of the $>35 \mu \mathrm{m}$ predators (Fig. 2a). This indicates that the first-order consumers of algae, i.e. the $\leq 35 \mathrm{\mu m}$ protozoa, were preyed upon by larger microzooplankton. The latter mainly consumed small protozoa, because the assemblage of $>3 \mu \mathrm{m}$ phytoplankton in Takapoto Lagoon mostly consists of 3 to $5 \mu \mathrm{m}$ Chlorophyceae (68\% of the total algal number), which are inefficiently captured by large microzooplankton. The 3 to $5 \mu \mathrm{m}$ Chlorophyceae are mainly consumed by $\leq 35 \mu \mathrm{m}$ heterotrophic dinoflagellates (Achradina and Prorocentrum), whose grazing, clearance, and ingestion rates were the highest among protozoa (Table 3; FLA). Moreover, in the absence of the large grazers, the 3 to $5 \mu \mathrm{m}$ algae are consumed at rates equivalent to their growth rates (Fig. 2a,b). Our data show that heterotrophic dinoflagellates consumed more nanophytoplankton than their potential competitors, the ciliates (Table 3). This is in contrast to previous studies in which heterotrophic dinoflagellates consumed less nanophytoplankton than the ciliates (e.g. Hansen 1992, Strom \& Morello 1998). It follows from our study that heterotrophic dinoflagellates, in at least some ecosystems, may be the main link between nanophytoplankton and large consumers.

The increased grazing activity of small consumers in the absence of predators could be due to an increase of their biomasses or/and the individual ingestion rates 
Some studies report increased growth rates of nanoprotozoa in the absence of large predators (Sherr et al. 1983, Kuosa 1991). Consistent with these findings, our results show that the growth rates of $\leq 35 \mu \mathrm{m}$ protozoa (Table 2) and their grazing rates on $>3 \mu \mathrm{m}$ algae (Fig. 2a) tripled when the large predators were removed. This indicates that the increased grazing activity of small protozoa likely reflects an increase in their biomasses, not in their individual ingestion rates. Similar to the large algae, the grazing mortality rates of small phytoplankton $(<1 \mu \mathrm{m}$ chl $a, 1$ to $3 \mu \mathrm{m}$ chl a, cyanobacteria, and $<3 \mu \mathrm{m}$ algae) significantly increased when the $>35 \mu \mathrm{m}$ grazers were removed (Figs. $2 \mathrm{a} \& 3 \mathrm{a}$ ). The protozoan grazing rates on heterotrophic bacteria remained unchanged, however, when the biomass of $\leq 35 \mu \mathrm{m}$ consumers augmented (i.e. free of predation), which implies that the small protozoa then decreased their individual bacterivory activity. This stresses the fact that the small heterotrophic bacteria of Takapoto are not optimal prey for the small grazers, who preferred, when free of predation, to graze larger food items (i.e. phytoplankton). The $\leq 35 \mu \mathrm{m}$ protozoan grazing rates on small and large phytoplankton were at least 4 times higher than those on heterotrophic bacteria (Fig. 2a). These results are consistent with our expectation of high grazing on cyanobacteria and algae when the removal rate of bacteria is low (see 'Introduction')

The specific growth rates of small phytoplankton were not affected by increased grazing activity of $\leq 35 \mu \mathrm{m}$ protozoa. The growth rates estimated for cyanobacteria and the $<3 \mu \mathrm{m}$ algae and those obtained for the $<1$ and 1 to $3 \mu \mathrm{m}$ chl a size fractions did not increase when the large grazers were removed (Figs. $2 \mathrm{~b} \& 3 \mathrm{~b}$ ). Our results do not agree with those of Reckermann \& Veldhuis (1997), who showed increased growth rates of Arabian Sea picophytoplankton when the large predators were removed from samples. In contrast to small phytoplankton, the $>3 \mu \mathrm{m}$ algae ( 3 to 5 and $>5 \mu \mathrm{m}$ ) increased their specific growth rates when subjected to increased grazing pressure (Fig. 2b). Similar results were obtained from the chl a-based dilution experiments (Fig. 3b). In our dilution experiments, it was shown above that the $>3 \mu \mathrm{m}$ algae were not $\mathrm{N}$ - or P-limited, but Sakka et al. (1999) showed, by using nutrient enrichment bioassays, that $>3 \mu \mathrm{m}$ algae may sometimes be Fe-limited. It follows that, in our experiments, a possible reason why the growth rates of $>3 \mu \mathrm{m}$ algae increased when they were subjected to a high grazing pressure was the enhanced regeneration of a nutrient (e.g. Fe) by small protozoa (Barbeau et al. 1996). Increases of nutrient regeneration upon removal of large grazers have also been reported in Chesapeake Bay (Glibert et al. 1992).
Previous experiments showed that nutrients exerted a bottom-up control on the biomass, growth, and species composition of the algal assemblage in the lagoon of Takapoto Atoll (Sakka et al. 1999). The present study provides evidence that grazing also exerts a strong top-down influence on the phytoplankton assemblage, i.e. the abundance and growth of phytoplankton is regulated by small protozoa, through grazing and nutrient regeneration. Given that the large protozoa control the grazing pressure of small protozoa, the interactions between large protozoan consumers and small protozoan grazers deeply influence the dynamics of phytoplankton. It follows that protozoa govern the structure of the planktonic food web in the lagoon of Takapoto Atoll.

\section{Structure of the planktonic food web}

The present study simultaneously investigated the grazing and growth of heterotrophic bacteria, cyanobacteria, and algae of the planktonic assemblage in the lagoon of Takapoto Atoll, so that it provides a complete picture of the structure of the planktonic food web. In the lagoon of Takapoto, the abundance of heterotrophic bacteria was high relative to other components of the planktonic food web. The fact that the planktonic food web in. Takapoto lagoon is characterized by low grazing on bacteria questions the idea that heterotrophic bacteria always play a major role in the flux of carbon through trophic links in the planktonic food web of oligotrophic systems (e.g. Weisse 1989, Rassoulzadegan 1993, Van Wambeke et al. 1996). Fig. 4 proposes a conceptual model for a microbial food web with low grazing on heterotrophic bacteria. In this planktonic system, heterotrophic bacteria take up dissolved organic carbon originating from phytoplankton exudation, zooplankton excretion, and sloppy feeding, but a small fraction only of the bacterial production enters the planktonic food web and reaches metazoa because of the low bacterivory of protozoa. Because of the low proportion of growing bacteria, the flow of carbon from bacteria to microzooplankton is $<4.3 \mu \mathrm{g} \mathrm{Cl}^{-1}$ $\mathrm{d}^{-1}\left(0.65 \mu \mathrm{g} \mathrm{Cl}^{-1} \mathrm{~d}^{-1}\right.$, for $12 \%$ active bacteria). The latter characteristic implies other mechanisms of carbon transfer, i.e. strong grazing of phytoplankton by microzooplankton. Small microzooplankton (mostly protozoa) are the major consumers of phytoplankton, with grazing rates corresponding to 74 and 56 to $100 \%$ of the algal growth rates, respectively. The flows of carbon from cyanobacteria and algae to microzooplank-

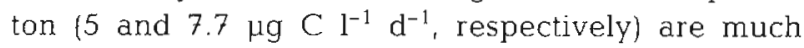
higher than the carbon bacterial flow. Large microzooplankton exert low grazing pressure on $\geq 3 \mu \mathrm{m}$ phytoplankton because these algae mostly consist of 3 to 


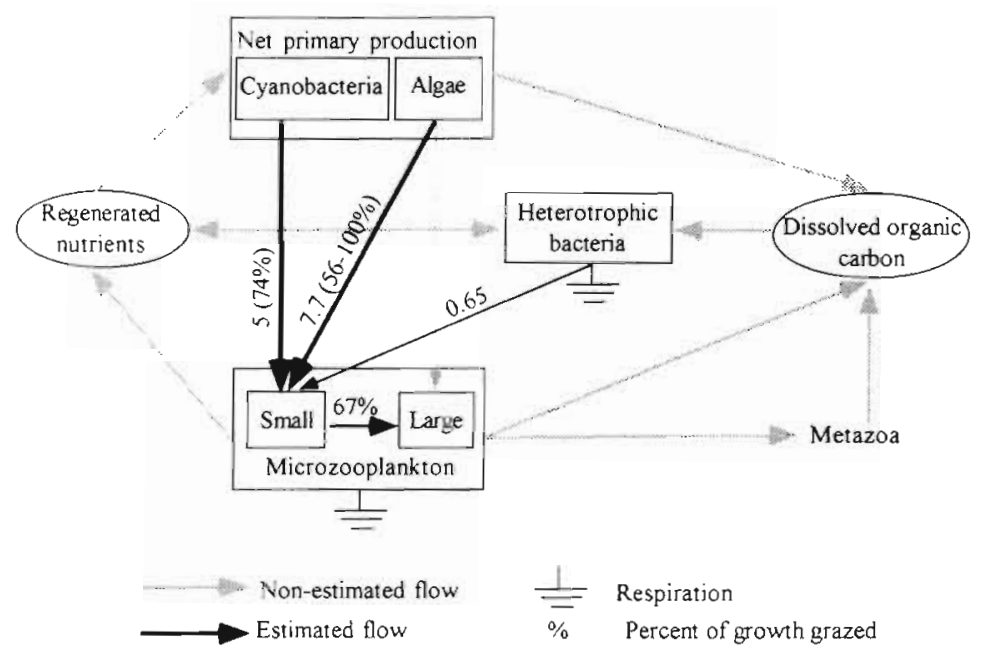

Fig. 4. Conceptual model of an oligotrophic planktonic food web with low grazing on heterotrophic bacteria. Widths of solid arrows indicate the magnitude of consumption rates by grazers (values given above the arrows: $\mu \mathrm{g} \mathrm{C} \mathrm{l}^{-1} \mathrm{~d}^{-1}$ ). Double-headed arrow between nutrients and bacteria reflects the fact that the latter may be net producers or net consumers of nutrients.

The food web is not detailed beyond the metazoan compartment

lagoon. Hence, Fig. 4 depicts a microbial food web based on phytoplankton, which is a microbial analogue of the herbivorous food web. This is an additional type of pathway in the trophic continuum described by Legendre \& Rassoulzadegan (1995)

\begin{abstract}
Acknowledgements. The present research was carried out in French Polynesia with the financial support of SRM (Service des Ressources Marines, Territorial Gouvernment of French Polynesia; to B.D.) and NSERC (Natural Sciences and Engineering Research Council of Canada; to L.L. and M.G.). We express our gratitude to the Director of the EVAAM station on Takapoto Atoll, G. Haumani, and his team for efficient assistance in the field. We thank $N$. Niquil and B. LeBlanc for help in the field, M. Berrodier for laboratory assistance in Laval University, B. Mostajir, and 4 anonymous reviewers for useful comments on the manuscript. This is a contribution to the research programme of GIROQ (Groupe interuniversitaire de recherches océanographiques du Québec).
\end{abstract}

\title{
LITERATURE CITED
}

$5 \mu \mathrm{m}$ taxa that are inefficiently captured by the Iarge grazers. The latter efficiently consume small microzooplankton (grazing rate equal to $67 \%$ of the growth rate), thus channeling a large part of the assimilated carbon to metazoa. Because cyanobacteria are the main primary producers, the grazing of protozoa on cyanobacteria, not on heterotrophic bacteria, is a major trophic pathway towards metazoan consumers in Takapoto lagoon.

In oligotrophic environments, heterotrophic bacteria generally compete successfully against phytoplankton for nutrients, taking advantage of their small size and high surface-to-volume ratio. The strong bacterivory of protozoa usually recycles nutrients and thus influences the competition between heterotrophic bacteria and autotrophic plankton (Azam et al. 1983). When the grazing pressure on heterotrophic bacteria is low, as in the lagoon of Takapoto Atoll, primary production may be sustained by alternative mechanismis of nutrient regeneration, e.g. in Fig 4 the grazing of microzooplankton on phytoplankton is the main processes of nutrient regeneration.

As explained in the 'Introduction', the microbial loop is an extreme case of the microbial food web, where microzooplankton feed almost exclusively on heterotrophic bacteria. Despite the fact that cyanobacteria belong to procaryotes and picoplankton as also do heterotrophic bacteria, the planktonic system schematized in Fig. 4 is very different from the microbial loop since microzooplankton almost exclusively graze cyanobacteria, which are the main primary producers in the
Anciersson A, Lãssoñ $U$, I lagström A (1986) Size sclcctive predation by a microflagellate on pelagic bacteria. Mar Ecol Prog Ser 33:51-57

Azam F (1998) Microbial control of oceanic carbon flux: the plot thickens. Science 280:694-696

Azam F, Fenchel $T$, Field JG, Gray JS, Meyer-Reil LA, Thingstad $F$ (1983) The ecological role of water-column microbes in the sea. Mar Ecol Prog Ser 10:257-263

Banse K (1982) Cell volume, maximal growth rates of unicellular algae and ciljates, and role of ciliates in the marine pelagial. Limnol Oceanogr 27:1059-1071

Barbeau K, Moffett JW, Caron DA, Croot PL, Erdner DL (1996) Role of protozoan grazing in relieving iron limitation of phytoplankton. Nature 380:61-63

Bernard C, Rassoulzadegan F (1993) The role of picoplankton (cyanobacteria and plastidic picoflagellates) in the diet of tintinnids. J Plankton Res 15:361-373

Bienfang PK, Morales L, Klein K, Takahashi M (1984) Picoplankton growth rates in subtropical Hawaiian embayment. Pac Sci 38:134-140

Booth $\mathrm{BC}$ (1987) The use of autofluorescence for analyzing oceanic phytoplankton communities. Bot Mar 30:101-108

Booth B (1988) Size classes and major taxonomic groups of phytoplankton at two locations in the subarctic Pacific Ocean in May and August 1984. Mar Biol 97:275-286

Campbell L, Carpenter EJ (1986) Estimating the grazing pressure of heterotrophic nanoplankton on Synechococcus spp. using the sea water dilution and selective inhibitor techniques. Mar Ecol Prog Ser 33:121-129

Capriulo GM (1990) Feeding-related ecology of marine protozod. In: Capriulo GM (ed) Ecology of marine protozoa. Oxford University Press, New York, p 186-257

Charpy L (1996) Phytoplankton biomass and production in two Tuamotu atoll lagoons (French Polynesia). Mar Ecol Prog Ser 145:133-142

Charpy L. Blanchot J (1998) Photosynthetic picoplankton in 
French Polynesian atoll lagoons: estimation of taxa contribution to biomass and production by flow cytometry. Mar Ecol Prog Ser 162:57-70

Charpy L, Dufour P, Garcia N (1997) Particulate organic matter in sixteen Tuamotu atoll lagoons (French Polynesia). Mar Ecol Prog Ser 151:55-65

Christaki U, Dolan JR, Pelegri S, Rassoulzadegan F (1998) Consumption of picoplankton-size particles by marine ciliates: effects of physiological state of the ciliate and particle quality. Limnol Oceanogr 43:458-464

Coffin RB, Sharp JH (1987) Microbial trophodynamics in the Delaware Estuary. Mar Ecol Prog Ser 41:253-266

Davis PG, Sieburth JM (1984) Estuarine and oceanic microflagellate predation of actively growing bacteria: estimation by frequency of dividing-divided bacteria. Mar Ecol Prog Ser 19:237-246

del Giorgio PA, Gasol JM, Vaque D, Mura P, Agusti S, Duarte CM (1996) Bacterioplankton community structure: protists control net production and the proportion of active bacteria in a coastal marine community. Limnol Oceanogr 41: $1169-1179$

Ducklow HW (1990) The biomass, production and fate of bacteria in coral reefs. In: Dubinsky Z (ed) Coral reefs, Vol 25. Elsevier, Amsterdam, p 265-290

Fenchel T (1982a) Ecology of heterotrophic microflagellates. I. Some important forms and their functional morphology. Mar Ecol Prog Ser 8:211-223

Fenchel $\mathrm{T}$ (1982b) Ecology of heterotrophic microflagellates. II. Bioenergetics and growth. Mar Ecol Prog Ser 8:225-231

Fenchel T (1982c) Ecology of heterotrophic microflagellates. III. Adaptations to heterogeneous environments. Mar Ecol Prog Ser 9:25-33

Fenchel T (1982d) Ecology of heterotrophic microflagellates. IV. Quantitative occurrence and importance as bacterial consumers. Mar Ecol Prog Ser 9:35-42

Ferrier-Pagès C, Gattuso JP (1998) Biomass, production and grazing rates of pico- and nanoplankton in coral reef waters (Miyako Island, Japan). Microb Ecol 35:46-57

Fuhrman JA, Noble RT (1995) Viruses and protists cause similar bacterial mortality in coastal seawater. Limnol Oceanogr 40:1236-1242

Fuhrman JA, Suttle CA (1993) Viruses in marine planktonic systems. Oceanography 6:51-63

Gifford DJ (1988) Impact of grazing by microzooplankton in the Northwest Arm of Halifax Harbour, Nova Scotia. Mar Ecol Prog Ser 47:249-258

Glibert PM, Miller CA, Garside C, Roman MR, McManus GB (1992) $\mathrm{NH}_{4}{ }^{+}$regeneration and grazing: interdependent processes in size fractionated ${ }^{15} \mathrm{NH}_{4}{ }^{+}$experiments. Mar Ecol Prog Ser 82:65-74

González JM (1996) Efficient size-selective bacterivory by phagotrophic nanoflagellates in aquatic ecosystems. Mar Biol 126:785-789

González JM, Sherr EB, Sherr BF (1990) Size-selective grazing on bacteria by natural assemblages of estuarine flagellates and ciliates. Appl Environ Microbiol 56:583-589

González JM, Sherr EB, Sherr BF (1993) Differential feeding by marine flagellates on growing versus starving, and on motile versus nonmotile, bacterial prey. Mar Ecol Prog Ser 102:257-267

González JM, Torréton JP, Dufour P, Charpy L (1998) Temporal and spatial dynamics of the pelagic microbial food web in an atoll lagoon. Aquat Microb Ecol 16:53-64

Hagström $\AA$, Azam F, Andersson A, Wikner J, Rassoulzadegan F (1988) Microbial loop in oligotrophic pelagic marine ecosystem: possible roles of cyanobacteria and nanoflagellates in the organic fluxes. Mar Ecol Prog Ser 49:171-178
Hansen PJ (1992) Prey size selection, feeding rates and growth dynamics of heterotrophic dinoflagellates with special emphasis on Gymnodinium spirale. Mar Biol 114 $327-334$

Havskum H, Hansen AS (1997) Importance of pigmented and colorless nano-sized protists as grazers on nanoplankton in a phosphate-depleted Norwegian fjord and in enclosures. Aquat Microb Ecol 12:139-151

Herndl GJ, Müller-Niklas G, Frick J (1993) Major role of ultraviolet-B in controlling bacterioplankton growth in the surface layer of the ocean. Nature 361:717-719

Hobbie JE, Daley RJ, Jasper S (1977) Use of Nuclepore filters for counting bacteria by fluorescence microscopy. Appl Environ Microbiol 33:1225-1228

Jeffrey WH, Pledger RJ, Aas P, Hager $S$, Coffin RB, Von Haven R, Mitchell DL (1996) Diel and depth profiles of DNA photodamage in bacterioplankton exposed to ambient solar ultraviolet radiation. Mar Ecol Prog Ser 137: $283-291$

Jonsson PR (1986) Particle size selection, feeding rates and growth dynamics of marine planktonic oligotrichous ciliates (Ciliphora: Oligotrichina). Mar Ecol Prog Ser 33: $265-277$

Kana TM, Glibert PM (1987) Effect of irradiance up to $2000 \mu \mathrm{E} \mathrm{m}^{-2} \mathrm{~s}^{-1}$ on marine Synechococcus WH7803-1 Growth, pigmentation and cell composition. Deep-Sea Res 34:479-516

Kuosa H (1991) Picoplanktonic algae in the northern Baltic Sea: seasonal dynamics and flagellate grazing. Mar Ecol Prog Ser 73:269-276

Landry MR (1993) Estimating rates of growth and grazing mortality of photoautotrophic plankton by dilution. In: Kemp PF, Sherr BF, Sherr EB, Cole JJ (eds) Handbook of methods in aquatic microbial ecology. Lewis Publishers, Boca Raton, p 715-722

Landry MR (1994) Methods and controls for measuring the grazing impact of planktonic protists. Mar Microb Food Webs 8:37-57

Landry MR, Hassett RP (1982) Estimating the grazing impact of marine micro-zooplankton. Mar Biol 67:283-288

Landry MR, Hass LW, Fagerness VL (1984) Dynamics of microbial plankton communities: experiments in Kaneohe Bay, Hawaii. Mar Ecol Prog Ser 16:127-133

Landry MR, Kirshtein J, Constantinou J (1995) A refined dilution technique for measuring the community grazing impact of microzooplankton, with experimental tests in the central equatorial Pacific. Mar Ecol Prog Ser 120:53-63

Le Borgne R, Rodier M, LeBouteiller A, Kulbicki M (1997) Plankton biomass and production in an open atoll lagoon Uvea, New Caledonia. J Exp Mar Biol Ecol 212:187-210

Legendre L, Le Fèvre J (1995) Microbial food webs and the export of biogenic carbon in ocean. Aquat Microb Ecol 9: $69-77$

Legendre L, Rassoulzadegan F (1995) Plankton and nutrient dynamics in marine waters. Ophelia 41:153-172

Lessard EJ, Swift E (1985) Species-specific grazing rates of heterotrophic dinoflagellates in oceanic waters, measured with a dual-label radioisotope technique. Mar Biol 87 : $289-296$

Linley EAS, Koop K (1986) Significance of pelagic bacteria as a trophic resource in coral reef lagoon, One Tree Island, Great Barrier Reef. Mar Biol 92:457-464

Liu H, Campbell L, Landry MR (1995) Growth and mortality rates of Prochlorococcus and Synechococcus measured with a selective inhibitor technique. Mar Ecol Prog Ser 116:277-287

Lund JWG, Kipling C, LeCren ED (1958) The inverted micro- 
scope method of estimating algal numbers and statistical basis of estimations by counting. Hydrobiologia 11: $143-170$

Marrasé C, Lin Lim E, Caron DA (1992) Seasonal and daily change in bacterivory in a coastal plankton community. Mar Ecol Prog Ser 82:218-289

Miller CA, Penry DL, Glibert PM (1995) The impact of trophic interactions on rates of nitrogen regeneration and grazing in Chesapeake Bay. Limnol Oceanogr 40:1005-1011

Nielsen TG, Løkkegaard B, Richardson $K$, Pedersen FB, Hansen L (1993) Structure of plankton communities in the Dogger Bank area (North Sea) during a stratified situation. Mar Ecol Prog Ser 95:115-131

Paffenhöfer GA (1998) Heterotrophic protozoa and small metazoa: feeding rates and prey-consumer interactions. J Plankton Res 20:121-133

Parsons TR, Maita Y, Lalli CM (1984) A manual of chemical and biological methods for seawater analysis. Pergamon Press, Oxford

Porter KG, Feig YS (1980) The use of DAPI for identifying and counting aquatic microflora. Limnol Oceanogr 25:943-948

Rassoulzadegan F (1993) Protozoan patterns in the AzamAmmerman's bacterial-phytoplankton mutualism. In Guerrero R, Pedros-Alio C (eds) Trends in microbial ecology. Spanish Society for Microbiology, Barcelona p $435-439$

Rassoulzadegan F, Sheldon RW (1986) Predation-prey interactions of nanozooplankton and bacteria in oligotrophic marine environment. Limnol Oceanogr 31:1010-1021

Reckermann M, Veldhuis MJW (1997) Trophic interactions between picophytoplankton and micro- and nanozooplankton in the western Arabian sea during the NE monsoon 1993. Aquat Microb Ecol 12:263-273

Riegman R, Kuipers BR, Noordeloos AAM, Witte HJ (1993) Size-differential control of phytoplankton and the structure of plankton communities. Neth J Sea Res 31:255-265

Roman MR, Ducklow HW, Fuhrman JA, Garside C, Glibert PM, Malone T, McManus GB (1988) Production, consumption and nutrient cycling in a laboratory mesocosm. Mar Ecol Prog Ser 42:39-52

Rublee PA, Gallegos CL (1989) Use of fluorescently labelled algae (FLA) to estimate microzooplankton grazing. Mar Ecol Prog Ser 51:221-227

Sakka A, Legendre L, Gosselin M, LeBlanc B, Delesalle B, Price N (1999) Nitrate, phosphate and iron limitation of the plankton assemblage in the lagoon of Takapoto Atoll (Tuamotu Archipelago, French Polynesia). Aquat Microb Ecol 19:149-161

Sanders RW, Wickham SA (1993) Planktonic protozoa and metazoa: predation, food quality and population control. Mar Microb Food Webs 7:197-223

Sherr BF, Sherr EB (1991) Proportional distribution of total numbers, biovolume, and bacterivory among size classes of 2-20 $\mu \mathrm{m}$ nonpigmented marine flagellates. Mar Microb Food Webs 5:227-237

Sherr BF, Sherr EB, Berman T (1983) Grazing, growth and ammonium excretion rates of a heterotrophic microflagellate fed with four species of bacteria. Appl Environ Microbiol 45:1196-1201

Sherr BF, Sherr EB, Andrew TL, Fallon RD, Newell SY (1986) Trophic interactions between heterotrophic protozoci and bacterioplankton in estuarine water analyzed with selective metabolic inhibitors. Mar Ecol Prog Ser 32:169-179

Sherr BF, Sherr EB, Fallon RD (1987) Use of monodispersed, fluorescently labelled bacteria to estimate in situ protozoan bacterivory. Appl Environ Microb 53.958-965

Sherr BF, Sherr EB, Pedros-Alió C (1989) Simultaneous mea- surement of bacterioplankton production and protozoan bacterivory in estuarine water. Mar Ecol Prog Ser 54 $209-219$

Sherr BF, Sherr EB, McDaniel J (1992) Effect of protistan grazing on the frequency of dividing cells in bacterioplankton assemblage. Appl Environ Microbiol 58: $2381-2385$

Sherr EB, Sherr BF (1993) Protistan grazing rates via uptake of fluorescently labelled prey. In: Kemp P, Sherr B, Sherr $E$, Coles $J$ (eds) Handbook of methods in aquatic microbial ecology. Lewis Publishers, Boca Raton, p 695-702

Sherr EB, Sherr BF (1994) Bacterivory and herbivory: key roles of phagotrophic protists in pelagic food webs. Microb Ecol 28:223-235

Sherr EB, Sherr BF, Paffenhöfer GA (1986) Phagotrophic protozoa as food for metazoans: a 'missing' trophic link in marine pelagic food webs? Mar Microb Food Webs 1 $61-80$

Sherr EB, Sherr BF, McDaniel J (1991) Clearance rates of $<6 \mu \mathrm{m}$ fluorescently labelled algae (FLA) by estuarine protozoa: potential grazing impact of flagellates and ciliates. Mar Ecol Prog Ser 69:81-92

Sieracki ME, Haas LW, Caron DA, Lessard EJ (1987) Effect of fixation on particle retention by microflagellates: underestimation of grazing rates. Mar Ecol Prog Ser 38:251-258

simek K, Vrba J, Hartman P (1994) Size selective feeding by Cyclidium sp. on bacterioplankton and various sizes of cultured bacteria. FEMS Microbiol Ecol 14:157-168

Simek K, Bobkova J, Macek M, Nedoma J, Psenner R (1995) Ciliate grazing on picoplankton in a eutrophic reservoir during the summer phytoplankton maximum: a study at the species and community levei. Limnoi Oceanuyr $4 \hat{u}$ : $1077-1090$

Sime-Ngando T, Gosselin M, Roy S, Chanut JP (1995) Significance of planktonic ciliated protozoa in the Lower St. Lawrence Estuary: comparison with bacterial, phytoplankton, and particulate organic carbon. Aquat Microb Ecol 9:243-258

Simon M, Azam F (1989) Protein content and protein synthesis rates of planktonic marine bacteria. Mar Ecol Prog Ser 51:201-213

Sournia A, Ricard $M$ (1976) Données sur l'hydrologie et la productivité du lagon d'un atoll fermé (Takapoto, île Tuamotu). Vie Milieu 26:243-279

Strom SL, Morello TA (1998) Comparative growth rates and yields of ciliates and heterotrophic dinoflagellates. J Plankton Res 20:571-585

Tamigneaux E, Mingelbier M, Klein B, Legendre L (1997) Grazing by protists and seasonal changes in the size structure of protozooplankton and phytoplankton in a temperate nearshore environment (western Gulf of St. Lawrence, Canada). Mar Ecol Prog Ser 146:231-247

Torréton JP, Dufour P (1996) Bacterioplankton production determined by DNA synthesis, protein synthesis, and frequency of dividing cells in Tuamotu Atoll lagoons and surrounding ocean. Microb Ecol 32:185-202

Utermöhl H (1931) Neue Wege in der quantitativen Erfassung des Planktons imit besonderer Berücksichtigung des Ultraplanktons). Verh Int Ver Theor Angew Limnol 5: $567-596$

Van Wambeke F, Christaki U, Gaudy R (1996) Carbon fluxes from the microbial food web to mesozooplankton. An approach in the surface layer of a pelagic area INW Mediterranean Sea). Oceanol Acta 19:57-66

Verity PG (1991) Measurement and simulation of prey uptake by marine planktonic ciliates fed plastidic and aplastidic nanoplankton. Limnol Oceanogr 36:729-750 
Verity PG, Smetacek V (1996) Organism life cycles, predation, and the structure of marine pelagic ecosystems. Mar Ecol Prog Ser 130:277-293

Vörös L, Balogh KV, Herodek S (1996) Microbial tood web in a large shallow lake (Lake Balaton, Hungary). Hydrobiologia 339:57-65

Vors $N$ (1992) Ultrastructure and autoecology of the marine heterotrophic flagellate Leucocryptos marina (Braarud) Butcher 1967 (Katablepharidaceae/Kathabelpharidae) with a discussion on the genera Leucocryptos and Kata-

Editorial responsibility: Otto Kinne (Editor),

Oldendorf/Luhe, Germany
blepharis/Kathablepharis. Eur J Protistol 28:369-389

Weisse $T$ (1989) The microbial loop in the Red Sea: dynamics of pelagic bacteria and heterotrophic nanoflagellates. Mar Ecol Prog Ser 55:241-250

Yoshinaga I, Fukami K, Ishida Y (1991) Comparison of DNA and protein synthesis rates of bacterial assemblages between coral reef waters and pelagic waters in tropical ocean. Mar Ecol Prog Ser 76:167-174

Zar JH (1984) Biostatistical analysis. Prentice-Hall, Englewood Cliffs

Submitted: November 17, 1998; Accepted: December 1, 1999 Proofs received from author(s): April 20, 2000 